\title{
Shifts in the Holstein dairy cow milk fat globule membrane proteome that occur during the first week of lactation are affected by parity
}

Mallory C. Honan ${ }^{1}$, Megan J. Fahey ${ }^{1}$, Amanda J. Fischer-Tlustos², Michael A. Steele ${ }^{2,3^{*}}$ and Sabrina L. Greenwood ${ }^{1 *}$ (D)

\begin{abstract}
Background: The milk fat globule membrane (MFGM) proteomes of colostrum and transition milk are rich sources of proteins that are likely important for neonatal calf health. In addition, characterization of these proteomes could also yield valuable information regarding mammary gland physiology of the early postpartum lactating cow. The objectives of this research were to characterize the MFGM proteomes of colostrum and transition milk through sample collections at four timepoints postpartum, including the first milking (M1, colostrum), second milking (M2, transition milk), fourth milking (M4, transition milk), and fourteenth milking (M14, mature milk), and compare these proteomes between multiparous (MP; $n=10$ ) and primiparous (PP; $n=10$ ) Holstein dairy cows. Isolated MFGM proteins were labeled using Tandem Mass tagging and analyzed using liquid chromatography-tandem mass spectrometry (LC-MS/MS). Protein identification was completed using MASCOT and Sequest in Proteome Discoverer 2.2. The scaled abundance values were analyzed using PROC MIXED in SAS to determine the effects of milking (MIL), parity (PAR), and MIL $\times$ PAR. The adaptive false-discovery rate (FDR)-adjusted $P$ values were determined using PROC MULTTEST. Protein characterization and bioinformatic analysis were completed using a combination of PANTHER, Blast, and Uniprot.
\end{abstract}

Results: A total of 104 common proteins were identified in each of the MFGM samples. Statistical analysis revealed that $70.2 \%$ of identified proteins were affected by MIL. Of these, 78.1\% were lower in M14 compared with M1, including immune-related proteins lactotransferrin, lactadherin and hemopexin. Parity affected $44.2 \%$ of proteins. Of the proteins affected by PAR, 84.8\% were higher in MP cows compared with PP cows, including apolipoprotein E and histones 2A, 2B, 3, and 4 b. Butyrophilin subfamily 1 member $1 \mathrm{~A}$ and annexin 5 were higher in samples from PP cows. Milking $\times$ parity affected $32.7 \%$ of identified proteins, including lactotransferrin, gelsolin, vitamin D binding protein, and S100 proteins.

\footnotetext{
* Correspondence: masteele@uoguelph.ca; sabrina.greenwood@uvm.edu

${ }^{2}$ Department of Animal Biosciences, University of Guelph, Guelph, ON N1G 2W1, Canada

${ }^{1}$ Department of Animal and Veterinary Sciences, The University of Vermont, Burlington, VT 05405, USA

Full list of author information is available at the end of the article
}

(c) The Author(s). 2020 Open Access This article is licensed under a Creative Commons Attribution 4.0 International License, which permits use, sharing, adaptation, distribution and reproduction in any medium or format, as long as you give appropriate credit to the original author(s) and the source, provide a link to the Creative Commons licence, and indicate if changes were made. The images or other third party material in this article are included in the article's Creative Commons licence, unless indicated otherwise in a credit line to the material. If material is not included in the article's Creative Commons licence and your intended use is not permitted by statutory regulation or exceeds the permitted use, you will need to obtain permission directly from the copyright holder. To view a copy of this licence, visit http://creativecommons.org/licenses/by/4.0/. The Creative Commons Public Domain Dedication waiver (http://creativecommons.org/publicdomain/zero/1.0/) applies to the data made available in this article, unless otherwise stated in a credit line to the data. 
(Continued from previous page)

Conclusions: This research supports previous findings that the Holstein MFGM proteome changes rapidly during the first week of lactation. In addition, this research identifies the impact of parity on the colostrum and transition milk MFGM proteomes, which may be important for milk-fed calf health or for the identification of protein biomarkers for mammary functionality.

Keywords: Colostrum, LC-MS/MS, Parity

\section{Background}

The bovine milk fat globule membrane (MFGM) proteome constitutes $1-4 \%$ of milk protein [1] and approximately $22 \%$ of the milk fat droplet [2]. Butyrophilin subfamily 1 member $1 \mathrm{~A}$ is highly abundant in the MFGM and comprises up to $40 \%$ of its proteome [3, 4]; however, the MFGM contains a diverse protein profile of several hundred proteins [5-7]. Biologically, the inclusion of intact MFGM in the diet supports the positive establishment of a healthy gut microbiome and protects against inflammation [8, 9]. Many of the proteins consistently identified within the MFGM support host immunity $[10,11]$ and also provide protection against enzymatic digestion [12]. Immune-associated bioactive properties of the MFGM may be of particular relevance in calf feeding protocols that include colostrum, transition milk, and mature milk [13-16].

The whey proteome rapidly shifts during the colostrum and transition milk period [5, 17-19], and examination of the colostral whey proteome's bioactivity [15] and sensitivity to processing $[18,20]$ has been explored. While some research has also explored the exosomal [21] and MFGM [5, 22] proteomes during this period, the profile of the MFGM-associated proteome during this early postpartum period is relatively poorly characterized. Reinhardt et al. [5] identified a higher abundance of proteins related to lipid transport synthesis in the MFGM of milk collected $7 \mathrm{~d}$ postpartum compared with the colostrum MFGM. Additionally, bioactive proteins such as xanthine dehydrogenase, butyrophilin, and adipophilin (also known as perilipin 2) were also higher in abundance in the transition milk MFGM compared with the colostrum MFGM [5].

Apart from being important nutritionally for the calf, characterization of the MFGM may also be valuable in developing our understanding of lactation physiology because the MFGM appears to be reflective of mammary secretory cell activity [3]. Identification and use of MFGM proteins as biomarkers of mammary health and functionality could enhance our diagnostic capabilities in the field to identify cows with mammary dysfunction or estimate relative mammary performance of individual cows.

The impact of parity on milk yield and milk profile, particularly fat content [23, 24], has been well documented. Due to allometric mammary tissue growth, primiparous (PP) heifers typically have higher energetic requirements during their first cycle of lactogenesis as compared to mature multiparous (MP) cows [25-27]. This additional mammary-driven energetic requirement may result in differential profiles of the MFGM proteome from cows of different maturities, as secretory mechanisms have reliance on cellular metabolism. For this research, it was hypothesized that the MFGM proteome will shift during the early postpartum period, specifically during the transition from colostrum to mature milk production. It was further hypothesized that parity would differentially affect this response due to the continued mammary gland development in PP versus MP cows. The objectives of this research were to characterize dynamic shifts in the MFGM proteome of both PP and MP Holstein cows across the first, second, fourth and fourteenth milking postpartum and comparatively analyze the impact of parity on this proteome.

\section{Materials and methods}

Experimental procedures were conducted in accordance with the Canadian Council of Animal Care [28] and all procedures were approved by the University of Alberta Animal Care and Use Committee for Livestock (AUP 00002015).

\section{Animals and sample collection}

Twenty Holstein dairy cows that were group-housed at Breevliet Farms Ltd. (Alberta, Canada) were included in the study. As outlined by Fischer-Tlustos et al. [29], all cows were fed the same dry cow diet before parturition and the same lactating cow diet after parturition. No cows displayed clinical signs of illness during the sampling period. For this trial, milk samples were collected from $10 \mathrm{PP}$ cows and $10 \mathrm{MP}$ cows (parity = 3.1 \pm 0.43 ). As described by Fahey et al. [30], all cows were milked twice daily (05:00 $\mathrm{h}$ and 16:00 h) and milk samples were collected from both groups using continuous in-line samplers at four milkings after parturition: 1) at the first milking postpartum (M1: $5.3 \pm 0.73 \mathrm{~h}$ after parturition; colostrum), 2) the second milking postpartum (M2; transition milk), 3) the fourth milking postpartum (M4; transition milk), and 4) the fourteenth milking postpartum (M14; mature milk). Milk yield and fat, protein, lactose, total solids, milk urea nitrogen, somatic cell count, and 
immunoglobulin $\mathrm{G}$ concentrations across milkings are outlined by Fischer-Tlustos et al. [29]. Aliquots of milk samples for the experiment presented herein were collected into $15 \mathrm{~mL}$ non-sterilized tubes (Catalogue\# 14959-53A, Thermo Scientific, Rockford, IL, USA), snap frozen in a dry ice/ethanol bath immediately after collection as per methods by Tacoma et al. [18], transported on dry ice to the University of Alberta (Edmonton, $A B$, Canada), and stored at $-80^{\circ} \mathrm{C}$. Samples were then shipped on dry ice to the University of Vermont (Burlington, VT, USA), and stored at $-80^{\circ} \mathrm{C}$ until proteomic analysis.

\section{MFGM protein fractionation}

Samples were thawed overnight at $4{ }^{\circ} \mathrm{C}$, and $400 \mu \mathrm{L}$ of protease inhibitor cocktail (Protease Inhibitor Cocktail, Catalogue \# P8340, Sigma Aldrich, St. Louis, MO, USA) was added to each tube. Two samples were deemed unusable during this preliminary processing due to transport damage, hence the remaining 78 samples were further processed. These 78 milk samples were centrifuged at $4,000 \times g$ at $4{ }^{\circ} \mathrm{C}$ and the cream layer was collected using a clean spatula and placed into a new $15-\mathrm{mL}$ tube. This separation step, including centrifugation and separation of the cream layer, was repeated. The cream layer was stored at $-80^{\circ} \mathrm{C}$ for MFGM proteome analysis.

Sample processing was performed as per methods established by Yang et al. [1] with minor modifications described herein. For proteomic analysis, up to $10 \mathrm{vol}-$ umes of phosphate buffered saline (PBS) was pipetted into each thawed sample and vortexed. All samples were then incubated for $20 \mathrm{~min}$ at $37^{\circ} \mathrm{C}$, centrifuged at $4,000 \times g$ for $30 \mathrm{~min}$, and PBS was aspirated. The addition of PBS, followed by a $20 \mathrm{~min}$ incubation at $37^{\circ} \mathrm{C}$, centrifugation at $4,000 \times g$ for $30 \mathrm{~min}$, and aspiration of the PBS, was repeated twice more for a total of three washes.

After washing with PBS, the cream was transferred into a new $50-\mathrm{mL}$ round-bottom Nalgene tube (Catalogue\#79013, United States Plastic Corp., Lima, OH, USA). Five volumes of lysis buffer $(50 \mathrm{mmol} / \mathrm{L}$ Tris- $\mathrm{HCl}$ at $\mathrm{pH} 7.4,4 \% \mathrm{SDS}$ (wt/vol) solution) was added to each tube and vortexed. These samples were incubated at room temperature for $1 \mathrm{~h}$ with periodic vortexing every $10-15 \mathrm{~min}$ and then subsequently incubated at $95^{\circ} \mathrm{C}$ for $5 \mathrm{~min}$. Samples were then centrifuged at $12,000 \times g$ for 15 min and the resulting fat layer was removed. The samples were again centrifuged at $12,000 \times g$ for $15 \mathrm{~min}$ and any residual fat was removed. The aqueous phase was collected through a transfer pipette and deposited into a new $15-\mathrm{mL}$ tube. An aliquot was then combined with acetone at a 1:6 ratio (sample: acetone) and incubated at $-20^{\circ} \mathrm{C}$ for $20 \mathrm{~h}$ immediately after mixing. Samples were then centrifuged at $14,000 \times g$ for $20 \mathrm{~min}$ at
$4{ }^{\circ} \mathrm{C}$ and the subsequent supernatant was discarded. Radioimmunoprecipitation assay (RIPA) buffer (Thermo Scientific, Rockford, IL, USA) was used to resuspend the pellet before storage at $-80^{\circ} \mathrm{C}$.

\section{Protein quantification and isobaric TMT labeling}

Processed samples were thawed on ice. To create one universal control (UC) that could later be used to compare against each individual sample, a composite UC mixture was created by combining aliquots of each animal. The final volume of UC was enough to later generate 9 identical aliquots from this one composite mixture for inclusion in each multiplex submitted for LC-MS/ MS analysis. The protein concentration of each individual sample $(n=78)$, as well as the UC $(n=1)$, was then determined using a bicinchoninic assay (BCA; Catalogue \#23225, Pierce Biotechnology, Rockford, IL, USA) kit. Samples and the UC were then subjected to isobaric labeling using Tandem Mass $\mathrm{Tag}^{\mathrm{Tm}}$ (TMT $^{\mathrm{mm}}$ ) 10plex Isobaric Labeling Kits (Pierce Biotechnology, Rockford, IL, USA). An aliquot of the UC was included as one sample in every multiplex to ensure consistent labeling and loading. In total, 9 multiplexes were created, each containing the UC and a randomized subset of the samples in order to complete a comparative analysis of the 78 samples. All LC-MS/MS analysis was completed at The Vermont Genetics Network Core Proteomics Facility (Burlington, VT, USA).

\section{Liquid chromatography-tandem mass spectrometry (LC- MS/MS)}

The purified TMT-labeled and combined peptides were resuspended in $2.5 \%$ acetonitrile $\left(\mathrm{CH}_{3} \mathrm{CN}\right)$ and $2.5 \%$ formic acid (FA) in water for subsequent LC-MS/MS based peptide identification and quantification. Analyses were performed on the Q-Exactive mass spectrometer coupled to an EASY-nLC ULTRA (Thermo Scientific, Waltham, MA, USA). Samples were loaded onto a $100 \mu \mathrm{m} \times 500 \mathrm{~mm}$ capillary column packed with Halo C18 $(2.7 \mu \mathrm{m}$ particle size, $90 \mathrm{~nm}$ pore size, Michrom Bioresources, CA, USA) at a flow rate of $300 \mathrm{~nL} / \mathrm{min}$. Program settings and parameters for LC-MS/MS analysis were performed as outlined by Scuderi et al. [31]. Briefly, the column end was laser pulled to a $\sim 3 \mu \mathrm{m}$ orifice and packed with minimal amounts of 5um Magic C18AQ before packing with the 3- $\mu \mathrm{m}$ particle size chromatographic materials. To separate peptides, the following gradient was used: $2.5-35 \% \mathrm{CH}_{3} \mathrm{CN} / 0.1 \%$ FA over $150 \mathrm{~min}, 35-100 \% \mathrm{CH}_{3} \mathrm{CN} / 0.1 \% \mathrm{FA}$ in $1 \mathrm{~min}$ and then $100 \% \mathrm{CH}_{3} \mathrm{CN} / 0.1 \% \mathrm{FA}$ for $8 \mathrm{~min}$, followed by an immediate return to $2.5 \% \mathrm{CH}_{3} \mathrm{CN} / 0.1 \% \mathrm{FA}$ and a hold at $2.5 \%$ $\mathrm{CH}_{3} \mathrm{CN} / 0.1 \%$ FA. A nanospray ionization source with a spray voltage of $2.0 \mathrm{kV}$ was used to introduce peptides. Mass spectrometry data was acquired in a data- 
dependent "Top 10" acquisition mode with lock mass function activated $(\mathrm{m} / z$ 371.1012; use lock masses: best; lock mass injection: full MS). A survey scan from $\mathrm{m} / \mathrm{z}$ $350-1600$ at 70,000 resolution (AGC target $1 e^{6}$; max IT $100 \mathrm{~ms}$; profile mode) was followed by 10 higher-energy collisional dissociation (HCD) tandem mass spectrometry (MS/MS) scans on the most abundant ions at 35, 000 resolution (AGC target $1 \mathrm{e}^{5}$; max IT $100 \mathrm{~ms}$; profile mode). MS/MS scans were acquired with an isolation width of $1.2 \mathrm{~m} / z$ and a normalized collisional energy of $35 \%$. Dynamic exclusion was enabled (peptide match: preferred; exclude isotopes: on; underfill ratio: $1 \%)$. Protein identification was completed using MASCOT and Sequest in Proteome Discoverer 2.2 (Thermo Scientific, Waltham, MA, USA) against a curated Uniprot Bos taurus protein database (3AUP000009136). The raw files were searched against the database as one contiguous input file, resulting in one result file. The peptide abundances in the labeled UC samples were set as 100 and the abundances of the proteins in the 78 experimental samples were scaled accordingly.

\section{Statistical and bioinformatic analysis}

The scaled abundance values of the identified proteins were statistically analyzed. Statistical analysis was performed using PROC MIXED of SAS (Version 9.4) and included cow as the subject and milking (MIL) as the repeated measure. The effects of MIL, parity (PAR), and MIL $\times$ PAR were determined. The adaptive false-discovery rate (FDR) adjusted treatment effects [32] were determined using PROC MULTTEST to account for multiple hypotheses testing. The accession number of the proteins that were labeled as "uncharacterized" were searched against the UniProt [33] database to obtain their FASTA sequences. The FASTA sequences of these proteins were then searched against the PANTHER version 14.1 [34] or BLAST [35] databases to identify the protein name. Accession numbers of identified proteins were searched against the the PANTHER Bos taurus database [34] to ascertain gene ontology (GO) annotations of identified proteins. Proteins were classified according to their biological processes. All GO classifications presented herein are presented as the percent of gene hits against the total number of genes.

\section{Results}

\section{Protein profile of the identified MFGM proteome}

Of the 104 proteins identified and analyzed in this study, the abundance of 78 proteins $(75 \%)$ changed in response to MIL, PAR, and/or MIL $\times$ PAR (Fig. 1). Xanthine dehydrogenase/oxidase, serum albumin, lactadherin, lactotransferrin, butyrophilin subfamily 1 member A1, and perilipin were present at the highest peptide counts (Supplementary Table S1). Annotation of the total proteome included cellular process (29\%), response to stimulus (25\%), and biological regulation (23\%) as the three primary biological process classifications encompassed by this proteome (Fig. 2). Differences between the total proteome GO profile and GO profiles of proteins affected by MIL and PAR were evident (Fig. 2): PAR impacted a greater proportion of proteins associated with cellular component organization and immune system processes, and MIL and PAR affected fewer proteins involved in localization compared with their representation in the total proteome.

\section{Proteins affected by MIL}

Milking affected $73(70.2 \%)$ of the 104 identified proteins. Of the 73 proteins impacted by MIL, 57 (78.1\%)

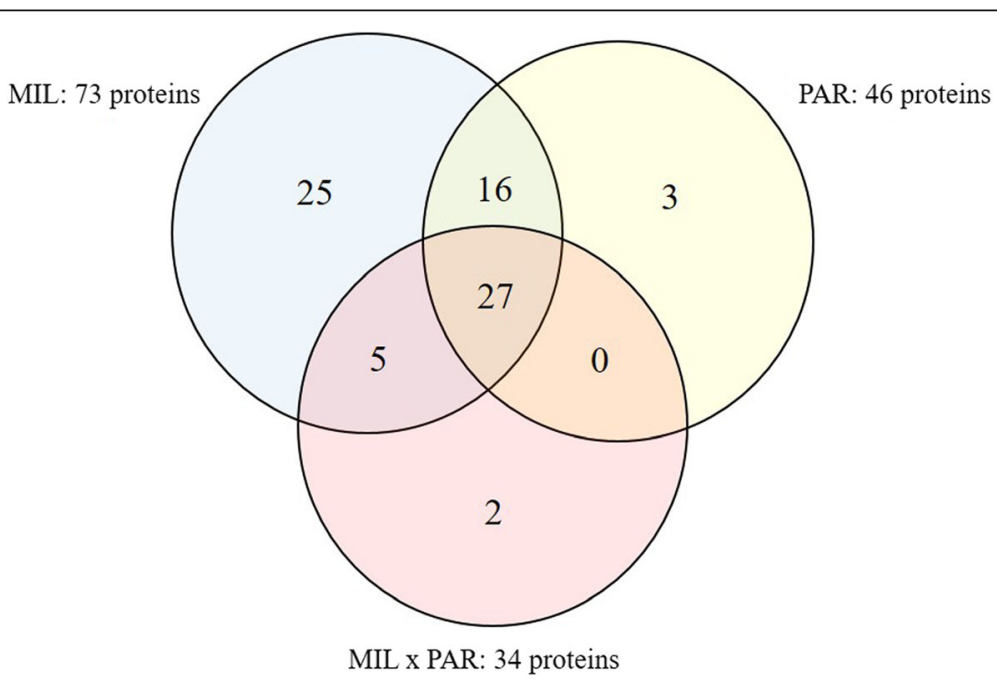

Fig. 1 Number of proteins affected by milking (MIL), parity (PAR), and MIL $\times$ PAR within the milk fat globule membrane (MFGM) collected from 10 primiparous (PP) and 10 multiparous (MP) Holstein dairy cows at four milkings postpartum (M1, M2, M4, M14) 


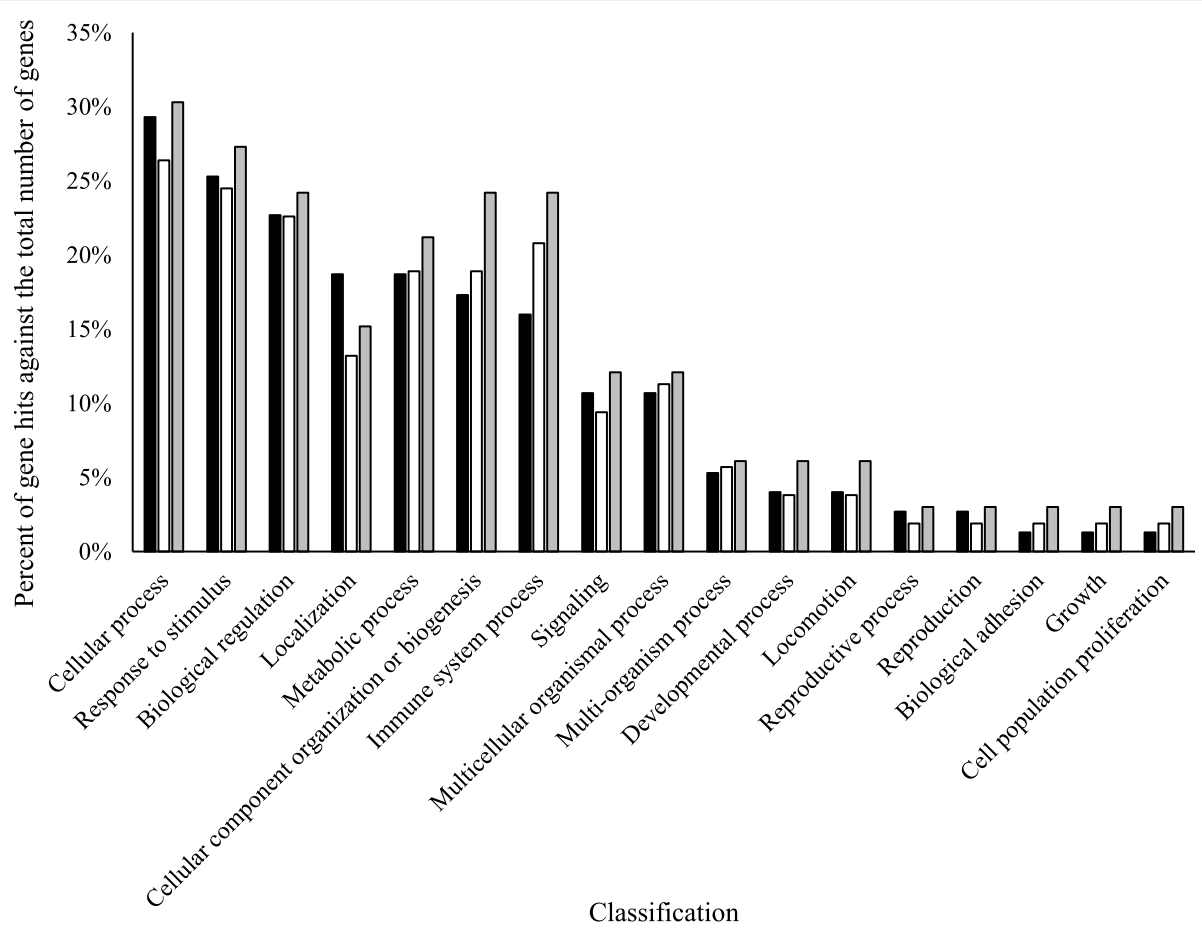

Fig. 2 Biological processes of the total proteome identified in the current trial (black bars), the proteins affected by milking (white bars), and the proteins affected by parity (grey bars)

were lower in abundance in M14 samples compared with M1 samples (Table 1). Examples of proteins within this grouping were lactotransferrin, lactadherin, vitamin $\mathrm{D}$ binding protein, hemopexin, and several immuneassociated proteins (examples: IgA, IgJ, IgK, IgL, IgM, CD177, CD5, serum amyloid A). Conversely, 16 proteins (21.9\%) were higher in abundance in M14 samples compared with M1 samples (Table 2). Proteins in this grouping included butyrophilin subfamily 1 member $1 \mathrm{~A}$, perilipin, and several binding proteins. Dominant GO classifications of these protein groupings is comparatively represented in Fig. 3. Higher representation of proteins involved in cellular process, biological regulation, immune system process, and localization was observed in proteins that were lower in abundance in M14 compared with M1. Proteins involved in the response to stimulus, multicellular organismal process, and signaling were more represented in the group of proteins of higher abundance in M14 compared with M1.

\section{Proteins affected by PAR}

Parity influenced the abundance of 46 proteins and 39 $(84.8 \%)$ of these proteins were higher in relative abundance in MP cows compared with PP cows (Table 3). Gelsolin, histones 1H1E, H2A, H2B, H3 and H4, apolipoprotein E, complement $\mathrm{C}$, lactotransferrin, keratin 1, and monocyte differentiation antigen CD14 are examples of proteins within this grouping. The remaining 7 proteins (15.2\%) were higher in PP cows compared with MP cows (Table 4), and examples include butyrophilin subfamily 1 member A1, apoliproteins A-I and C-III, cytochrome b reductase 1 , and annexin 5 . Only 3 proteins were affected only by PAR and not by MIL or MIL $\times$ PAR: monocyte differentiation antigen CD14, keratin 1 , and annexin 5 .

\section{Proteins affected by MIL $\times$ PAR}

A total of 34 proteins (32.7\% of identified proteins) were influenced by the interaction of MIL $\times$ PAR, and only $43.6 \%$ of these were affected by either MIL or PAR independently (Table 5). Affected proteins include vitamin D-binding protein, lactotransferrin, complement $\mathrm{C} 3$, clusterin, gelsolin, and protein S100 variants. The biological processes of the proteins that had altered abundance due to the interaction of MIL $\times$ PAR were diverse and similar in profile to the biological processes of the total proteome characterized in this experiment (data not shown). Of the 34 affected proteins, 25 (73.5\%) followed a similar pattern, whereby MP cows had a higher abundance compared with PP cows in M1, and by M14 the protein abundance was similar within protein across PP and MP cows. Within this grouping, protein S100 variants 8, 9, and 12 are examples of proteins displaying this pattern (Fig. 5). Of exception to this pattern were the following 9 proteins: folate receptor 2 (Fetal), apolipoprotein C-III, selenoprotein F, Fc-gamma-RII-D, BOLA class I histocompatibility antigen, alpha chain BL3-7, 
Table 1 Milk fat globule membrane proteins secreted by 10 primiparous (PP) and 10 multiparous (MP) Holsteins at four milkings postpartum (M1, M2, M4, M14) that were affected by milking (MIL) and had lower abundance at M14 compared with M1

\begin{tabular}{|c|c|c|c|c|c|c|c|c|c|c|}
\hline \multirow{2}{*}{$\begin{array}{l}\text { Accession } \\
\text { number }\end{array}$} & \multirow[t]{2}{*}{ Description } & \multicolumn{2}{|l|}{ M1 } & \multicolumn{2}{|l|}{ M2 } & \multicolumn{2}{|l|}{ M4 } & \multicolumn{2}{|l|}{ M14 } & \multirow{2}{*}{$\begin{array}{l}P \text { - } \\
\text { value }\end{array}$} \\
\hline & & Value & SE & Value & SE & Value & SE & Value & SE & \\
\hline A0A0A0MP90 & Histone $\mathrm{H} 2 \mathrm{~A}$ & 92.0 & 26.1 & 106.2 & 15.5 & 103.2 & 24.2 & 30.7 & 6.2 & $<.0001$ \\
\hline AOA0N4STN1 & Cathelicidin-1-like & 116.1 & 14.6 & 100.6 & 10.6 & 96.2 & 7.3 & 63.7 & 8.6 & 0.0043 \\
\hline A0A140T881 & Apolipoprotein E & 116.8 & 11.5 & 110.7 & 10.1 & 100.8 & 5.7 & 78.5 & 6.7 & 0.0079 \\
\hline A8DC37 & Fc-gamma-RII-D & 154.7 & 14.3 & 148.0 & 17.8 & 84.6 & 7.5 & 44.8 & 3.2 & $<.0001$ \\
\hline E1BF48 & CD177 molecule & 94.8 & 27.0 & 108.1 & 14.7 & 97.0 & 18.8 & 32.8 & 5.9 & $<.0001$ \\
\hline E1BGN3 & Histone H3 & 83.1 & 27.1 & 97.1 & 12.7 & 102.3 & 22.6 & 36.6 & 6.1 & $<.0001$ \\
\hline F1MCF8 & IGL@ protein & 146.8 & 34.6 & 86.4 & 9.8 & 56.0 & 7.4 & 21.1 & 2.7 & $<.0001$ \\
\hline $\mathrm{F} 1 \mathrm{MH} 40$ & IGK protein & 151.6 & 26.9 & 99.3 & 9.2 & 64.7 & 7.8 & 29.4 & 3.1 & $<.0001$ \\
\hline $\mathrm{F} 1 \mathrm{MHH} 9$ & Low affinity immunoglobulin gamma Fc region receptor II & 146.2 & 22.9 & 112.7 & 15.9 & 80.8 & 9.5 & 45.1 & 3.8 & $<.0001$ \\
\hline F1MHS5 & Protein S100-A9 & 115.2 & 26.6 & 109.7 & 16.2 & 99.8 & 16.3 & 32.0 & 5.3 & $<.0001$ \\
\hline F1MLW8 & Immunoglobulin lambda-1 light chain-like isoform X5 & 133.9 & 20.2 & 84.2 & 10.4 & 69.3 & 16.6 & 35.2 & 3.7 & $<.0001$ \\
\hline F1MLZ1 & Cytochrome b reductase 1 & 143.2 & 25.3 & 95.9 & 16.0 & 77.8 & 8.5 & 39.3 & 5.0 & $<.0001$ \\
\hline F1MMW8 & Serum amyloid A protein & 116.1 & 11.0 & 118.7 & 18.7 & 108.5 & 10.4 & 69.4 & 8.1 & 0.0016 \\
\hline F1MUD2 & Histone $\mathrm{H} 2 \mathrm{~B}$ & 88.5 & 36.8 & 102.2 & 14.1 & 104.3 & 26.5 & 32.8 & 6.7 & $<.0001$ \\
\hline F1MX83 & Protein S100 & 134.6 & 19.0 & 119.9 & 9.4 & 95.4 & 8.5 & 61.6 & 6.3 & $<.0001$ \\
\hline F1MXX6 & Lactadherin & 130.5 & 11.0 & 118.7 & 12.8 & 92.9 & 8.4 & 75.6 & 8.9 & 0.001 \\
\hline F1N116 & Gelsolin & 124.6 & 13.1 & 107.7 & 9.1 & 95.2 & 6.1 & 65.5 & 5.9 & $<.0001$ \\
\hline F1N4Y5 & Non-classical MHC class I antigen precursor & 131.4 & 10.1 & 130.4 & 15.1 & 94.8 & 7.8 & 68.4 & 5.4 & $<.0001$ \\
\hline F1N514 & CD5 antigen-like precursor & 153.3 & 14.0 & 115.8 & 12.5 & 62.4 & 4.8 & 32.7 & 3.1 & $<.0001$ \\
\hline F1N5M2 & Vitamin D-binding protein & 147.1 & 17.2 & 96.6 & 11.2 & 67.9 & 6.5 & 40.0 & 3.4 & $<.0001$ \\
\hline F1N650 & Annexin & 97.5 & 29.5 & 86.1 & 14.9 & 117.3 & 19.2 & 50.5 & 7.6 & 0.0044 \\
\hline F1N726 & Glycoprotein 2 & 97.9 & 12.3 & 132.2 & 13.7 & 94.6 & 11.7 & 51.1 & 7.7 & $<.0001$ \\
\hline G3MWV5 & Histone cluster $1 \mathrm{H} 1$ family member e & 89.9 & 41.4 & 94.2 & 13.7 & 86.9 & 23.5 & 21.9 & 3.3 & $<.0001$ \\
\hline G3MXB5 & Immunoglobulin IgA heavy chain constant region, partial & 110.4 & 13.3 & 132.8 & 13.8 & 69.7 & 8.4 & 26.0 & 4.7 & $<.0001$ \\
\hline G3NOVO & Secreted immunoglobulin gamma2 heavy chain constant region, partial & 137.1 & 37.2 & 67.9 & 10.2 & 81.0 & 26.7 & 30.1 & 5.3 & 0.0005 \\
\hline G3N2D7 & Immunoglobulin light chain, partial & 105.0 & 9.0 & 83.0 & 6.8 & 76.1 & 6.5 & 45.8 & 4.2 & $<.0001$ \\
\hline G3X7A5 & Complement C3 & 123.4 & 17.5 & 91.1 & 8.8 & 102.2 & 12.6 & 71.1 & 6.5 & 0.0124 \\
\hline G5E513 & IgM heavy chain constant region, secretory form, partial & 150.9 & 14.4 & 119.0 & 14.7 & 65.2 & 5.2 & 36.5 & 3.3 & $<.0001$ \\
\hline G5E5T5 & Immunoglobulin M heavy chain secretory form & 146.2 & 13.8 & 117.2 & 13.2 & 67.6 & 5.1 & 45.8 & 3.7 & $<.0001$ \\
\hline G5E5V1 & Immunoglobulin iota chain-like, partial (TPA) & 135.3 & 21.0 & 94.0 & 8.0 & 65.1 & 8.9 & 28.9 & 4.9 & $<.0001$ \\
\hline G5E604 & TPA: immunoglobulin iota chain-like & 136.0 & 16.6 & 95.9 & 12.3 & 66.4 & 12.1 & 34.6 & 4.1 & $<.0001$ \\
\hline P01888 & Beta-2-microglobulin & 110.0 & 46.5 & 93.0 & 16.6 & 90.1 & 16.4 & 35.3 & 5.6 & 0.0004 \\
\hline P08037 & Beta-1,4-galactosyltransferase 1 & 127.3 & 13.3 & 132.0 & 17.3 & 92.3 & 13.9 & 54.1 & 5.9 & $<.0001$ \\
\hline P08728 & Keratin, type I cytoskeletal 19 & 116.9 & 10.5 & 134.6 & 13.1 & 91.0 & 8.2 & 51.4 & 4.6 & $<.0001$ \\
\hline P13753 & BOLA class I histocompatibility antigen, alpha chain BL3-7 & 107.6 & 10.0 & 127.8 & 22.4 & 100.8 & 7.8 & 75.1 & 7.0 & 0.0103 \\
\hline P15497 & Apolipoprotein A-I & 135.1 & 10.2 & 141.0 & 17.1 & 116.3 & 7.5 & 73.7 & 5.4 & $<.0001$ \\
\hline P17697 & Clusterin & 148.6 & 11.2 & 139.7 & 13.8 & 75.3 & 7.4 & 37.1 & 3.8 & $<.0001$ \\
\hline P19035 & Apolipoprotein C-III & 145.0 & 15.3 & 142.5 & 18.4 & 77.4 & 5.4 & 45.6 & 3.6 & $<.0001$ \\
\hline P24627 & Lactotransferrin & 118.0 & 32.4 & 76.6 & 9.8 & 75.5 & 8.5 & 43.7 & 4.3 & 0.0003 \\
\hline P28782 & Protein S100-A8 & 110.9 & 23.9 & 113.4 & 16.2 & 95.5 & 17.3 & 30.9 & 4.3 & $<.0001$ \\
\hline P48616 & Vimentin & 112.6 & 18.7 & 108.2 & 10.5 & 104.8 & 13.4 & 51.7 & 5.5 & $<.0001$ \\
\hline P56425 & Cathelicidin-7 & 92.7 & 17.0 & 115.3 & 21.0 & 120.7 & 16.0 & 47.5 & 5.7 & $<.0001$ \\
\hline
\end{tabular}


Table 1 Milk fat globule membrane proteins secreted by 10 primiparous (PP) and 10 multiparous (MP) Holsteins at four milkings postpartum (M1, M2, M4, M14) that were affected by milking (MIL) and had lower abundance at M14 compared with M1 (Continued)

\begin{tabular}{|c|c|c|c|c|c|c|c|c|c|c|}
\hline \multirow{2}{*}{$\begin{array}{l}\text { Accession } \\
\text { number }\end{array}$} & \multirow[t]{2}{*}{ Description } & \multicolumn{2}{|l|}{ M1 } & \multicolumn{2}{|l|}{ M2 } & \multicolumn{2}{|l|}{ M4 } & \multicolumn{2}{|l|}{ M14 } & \multirow{2}{*}{$\begin{array}{l}P \text { - } \\
\text { value }\end{array}$} \\
\hline & & Value & SE & Value & SE & Value & SE & Value & SE & \\
\hline P60712 & Actin, cytoplasmic 1 & 126.6 & 19.0 & 109.4 & 10.4 & 90.4 & 7.4 & 58.8 & 5.1 & $<.0001$ \\
\hline P62261 & 14-3-3 protein epsilon & 121.9 & 8.6 & 116.9 & 11.2 & 99.3 & 8.1 & 87.8 & 9.4 & 0.0397 \\
\hline P62803 & Histone H4 & 98.0 & 35.8 & 105.6 & 12.3 & 108.2 & 23.7 & 36.4 & 6.4 & $<.0001$ \\
\hline P62992 & Ubiquitin-40S ribosomal protein \$27a & 129.0 & 11.2 & 112.8 & 11.3 & 113.8 & 11.1 & 90.2 & 7.8 & 0.0338 \\
\hline P79105 & Protein S100-A12 & 116.4 & 16.1 & 121.4 & 14.7 & 93.3 & 17.4 & 30.3 & 5.0 & $<.0001$ \\
\hline P81265 & Polymeric immunoglobulin receptor & 112.9 & 12.4 & 122.5 & 13.5 & 80.9 & 6.6 & 40.6 & 4.8 & $<.0001$ \\
\hline P81644 & Apolipoprotein A-II & 120.1 & 13.0 & 128.3 & 14.9 & 102.2 & 7.1 & 85.2 & 8.8 & 0.041 \\
\hline QOVCN9 & Folate receptor 2 (Fetal) & 150.4 & 11.0 & 121.9 & 13.7 & 78.1 & 4.3 & 43.3 & 3.1 & $<.0001$ \\
\hline Q17QG8 & Histone $\mathrm{H} 2 \mathrm{~A}$ & 81.5 & 27.4 & 105.7 & 15.1 & 96.6 & 21.2 & 29.6 & 5.7 & $<.0001$ \\
\hline Q1JPB0 & Leukocyte elastase inhibitor & 132.9 & 23.2 & 93.0 & 10.1 & 86.0 & 8.6 & 46.7 & 6.2 & $<.0001$ \\
\hline Q29S21 & Keratin, type II cytoskeletal 7 & 111.6 & 9.2 & 131.8 & 12.6 & 102.2 & 7.6 & 74.3 & 5.3 & $<.0001$ \\
\hline Q2KII3 & Hepatitis A virus cellular receptor $1 \mathrm{~N}$-terminal domain containing protein & 127.3 & 9.2 & 116.9 & 13.3 & 105.8 & 7.6 & 68.3 & 3.9 & $<.0001$ \\
\hline Q3SYR8 & Immunoglobulin J chain & 124.3 & 8.8 & 111.7 & 7.8 & 76.4 & 4.2 & 42.9 & 4.8 & $<.0001$ \\
\hline Q3SZV77 & Hemopexin & 134.8 & 17.3 & 99.9 & 10.4 & 89.3 & 12.1 & 51.6 & 8.3 & $<.0001$ \\
\hline Q8SQ28 & Serum amyloid A protein & 123.8 & 11.6 & 133.5 & 22.9 & 109.2 & 11.4 & 67.5 & 9.7 & 0.001 \\
\hline
\end{tabular}

serum amyloid A protein, CD59 molecule (CD59 blood group), clusterin, and apolipoprotein A-I. While folate receptor 2 (Fetal), apolipoprotein C-III, Fc-gamma-RII-D, BOLA class I histocompatibility antigen, alpha chain BL37, serum amyloid A protein, clusterin, and apolipoprotein A-I were affected by at least 1 main effect in addition to the interaction, selenoprotein $\mathrm{F}$ and CD59 molecule (CD59 blood group) were impacted by MIL $\times$ PAR but were not affected by the main effects of MIL or PAR due to the pattern of change within these 2 proteins.

\section{Discussion}

In the current study, we characterized the MFGM proteomes of colostrum and transition milk and examined the

Table 2 Milk fat globule membrane proteins secreted by 10 primiparous (PP) and 10 multiparous (MP) Holsteins at four milkings postpartum (M1, M2, M4, M14) that were affected by milking (MIL) and had higher abundance at M14 compared with M1

\begin{tabular}{|c|c|c|c|c|c|c|c|c|c|c|}
\hline \multirow{2}{*}{$\begin{array}{l}\text { Accession } \\
\text { number }\end{array}$} & \multirow[t]{2}{*}{ Description } & \multicolumn{2}{|l|}{ M1 } & \multicolumn{2}{|l|}{ M2 } & \multicolumn{2}{|l|}{ M4 } & \multicolumn{2}{|l|}{ M14 } & \multirow{2}{*}{$\begin{array}{l}P \text { - } \\
\text { value }\end{array}$} \\
\hline & & Value & SE & Value & SE & Value & SE & Value & SE & \\
\hline Q8WML4 & Mucin-1 & 63.0 & 4.0 & 80.4 & 6.2 & 154.7 & 16.3 & 220.3 & 29.4 & $<.0001$ \\
\hline P10790 & Fatty acid-binding protein, heart & 68.5 & 5.0 & 78.6 & 7.5 & 144.5 & 14.6 & 235.9 & 32.7 & $<.0001$ \\
\hline B2D1N9 & ATP-binding cassette sub-family $\mathrm{G}$ member 2 & 84.4 & 4.1 & 84.0 & 7.4 & 125.0 & 13.1 & 239.3 & 33.6 & $<.0001$ \\
\hline P80195 & Glycosylation-dependent cell adhesion molecule 1 & 56.4 & 6.2 & 67.2 & 9.3 & 164.1 & 16.8 & 261.3 & 37.9 & $<.0001$ \\
\hline F1N1N6 & Perilipin & 83.0 & 5.5 & 101.1 & 9.6 & 123.5 & 13.6 & 205.3 & 29.8 & 0.0002 \\
\hline P02663 & Alpha-S2-casein & 72.7 & 13.3 & 77.0 & 13.1 & 150.9 & 24.7 & 150.9 & 18.0 & 0.0006 \\
\hline P18892 & Butyrophilin subfamily 1 member A1 & 87.3 & 5.0 & 104.3 & 9.3 & 130.3 & 15.4 & 171.0 & 23.7 & 0.0008 \\
\hline F1MGC2 & Non-secretory ribonuclease isoform $\mathrm{X} 1$ & 87.0 & 8.2 & 92.3 & 13.0 & 150.0 & 21.2 & 140.7 & 13.3 & 0.0013 \\
\hline F1N6D4 & Sodium-dependent phosphate transport protein $2 \mathrm{~B}$ & 95.1 & 5.5 & 96.2 & 9.6 & 126.1 & 12.4 & 175.0 & 23.8 & 0.0032 \\
\hline E1BHI7 & Butyrophilin subfamily 1 member A1 & 87.9 & 9.4 & 101.2 & 14.2 & 138.9 & 21.8 & 205.4 & 33.7 & 0.0041 \\
\hline Q0॥G8 & Ras-related protein Rab-18 & 98.0 & 4.8 & 103.0 & 9.2 & 126.7 & 11.6 & 161.5 & 21.3 & 0.0083 \\
\hline Q2KIS4 & Dehydrogenase/reductase (SDR family) member 1 & 93.7 & 5.5 & 103.4 & 10.1 & 133.4 & 11.4 & 116.0 & 11.7 & 0.0149 \\
\hline P02662 & Alpha-S1-casein & 76.8 & 12.2 & 88.3 & 18.3 & 130.1 & 24.5 & 162.6 & 26.3 & 0.0163 \\
\hline P10152 & Angiogenin-1 & 84.0 & 9.1 & 78.0 & 11.6 & 108.8 & 13.2 & 175.0 & 34.8 & 0.0298 \\
\hline P00711 & Alpha-lactalbumin & 54.8 & 15.0 & 30.7 & 5.1 & 152.9 & 66.0 & 127.6 & 48.8 & 0.0331 \\
\hline Q3SYS6 & Calcineurin B homologous protein 1 & 107.0 & 11.5 & 107.0 & 7.5 & 136.2 & 8.4 & 130.8 & 11.4 & 0.0376 \\
\hline
\end{tabular}




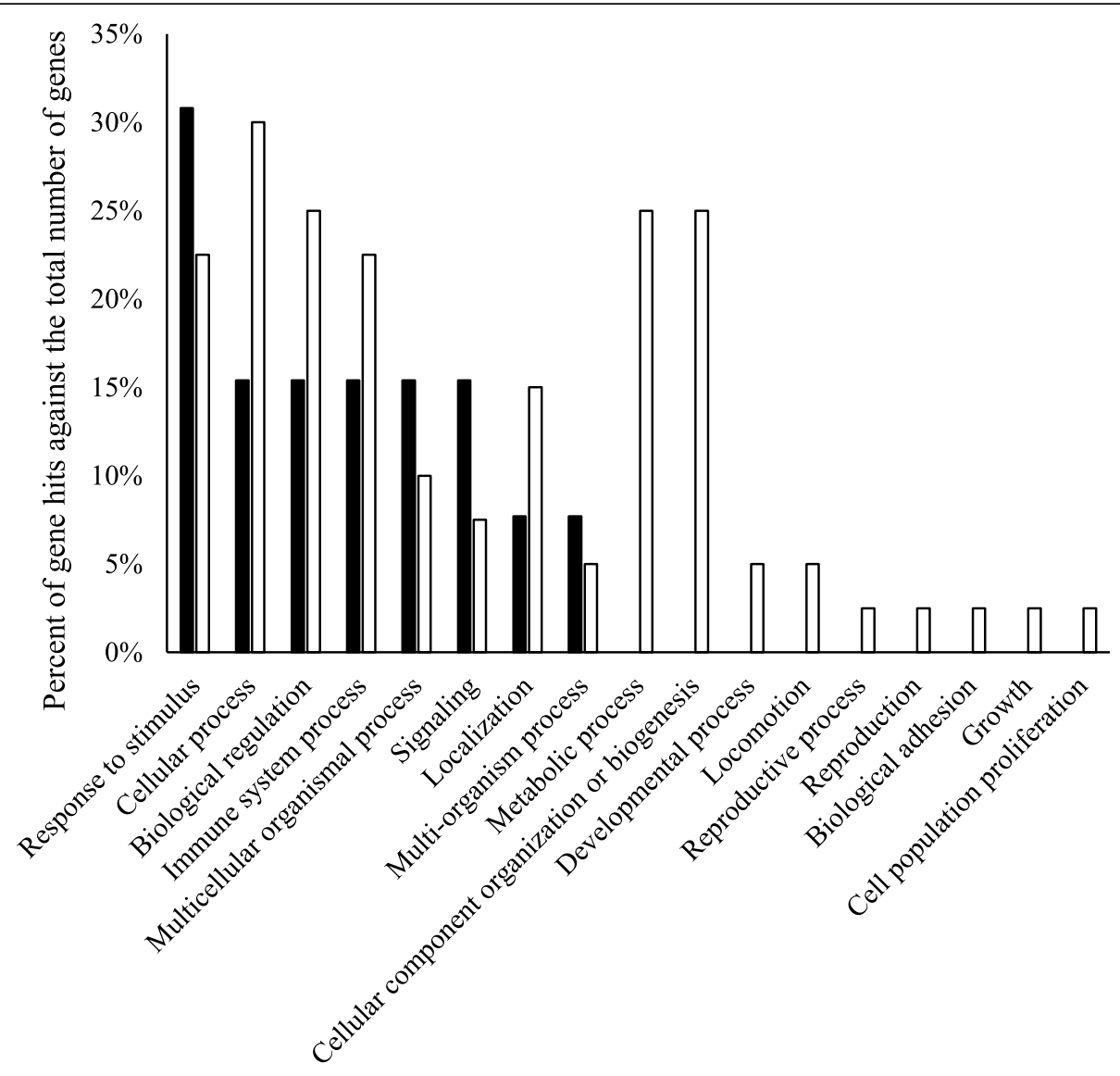

Classification

Fig. 3 Biological processes of proteins that were impacted by milking. Proteins that were higher at the fourteenth milking postpartum (M14) compared with the first milking postpartum (M1) are displayed in black. Proteins that were lower at the fourteenth milking postpartum (M14) compared with the first milking postpartum (M1) are displayed in white

impact of PAR on these proteomes. Consistent with previous reports [36], the MFGM proteome was rich in proteins involved in cellular process, regardless of MIL or PAR of the cow. Recent work by Yang et al. [37] identified the response to stimulus and localization GO classifications to encompass $19 \%$ and $18 \%$ of the colostrum proteome, respectively, which is in line with our findings. The protein profile identified in the current trial was also consistent with previous research $[1,5,9,37]$, and included the highly abundant MFGM proteins xanthine dehydrogenase/oxidase, serum albumin, butyrophilin subfamily 1 member $1 \mathrm{~A}$, lactadherin, lactotransferrin, and perilipin 2. The importance of these proteins in aspects of milk fat droplet formation, docking and secretion is well documented [38-40], and their higher abundance relative to other proteins is in line with other reports $[1,5,37]$. Xanthine dehydrogenase/ oxidase and serum albumin were 2 of the 26 proteins that were not affected by MIL, PAR or their interaction; however, the observed shift in 78 of the identified proteins (75\%) demonstrates the broad impact that mammary functionality has on the MFGM proteome.
In the research presented herein, MIL was the dominant variable affecting $70.2 \%$ of identified proteins (Tables 1 and 2). Approximately $78 \%$ of proteins affected by MIL were higher in abundance in M1 compared with M14. Metabolically, the onset of colostrogenesis signals an immense shift in protein metabolism and synthesis in the mammary gland. The high protein concentration within colostrum [29], along with increasing amino acid uptake and protein synthesis in the mammary gland [41, 42], both underscore this shift. Our observation of higher abundances of histones, actin regulators, and other indicators of protein synthesis support the inclusion of proteinmediated regulation that results in an altered MFGM proteome. While Immunoglobulin G has historically been perceived as the prime indicator of colostrum quality, other proteins may also be important contributors to the healthfulness of colostrum [18, 43]. Reinhardt et al. [5] comparatively explored the MFGM proteomes from cows at parturition and $7 \mathrm{~d}$ postpartum, which equates to our M1 versus M14 comparison. These researchers observed that approximately $33 \%$ of the proteome was affected by 
Table 3 Milk fat globule membrane proteins that were present at lower abundance in colostrum and milk collected at milkings 1, 2, 4 , and 14 postpartum from primiparous (PP; $n=10)$ cows compared with multiparous (MP, $n=10)$ cows. Average abundance across milkings is presented within parity

\begin{tabular}{|c|c|c|c|c|c|c|}
\hline \multirow{2}{*}{$\begin{array}{l}\text { Accession } \\
\text { number }\end{array}$} & \multirow[t]{2}{*}{ Description } & \multicolumn{2}{|l|}{ MP } & \multicolumn{2}{|l|}{ PP } & \multirow{2}{*}{$\begin{array}{l}P- \\
\text { value }\end{array}$} \\
\hline & & Value & SE & Value & SE & \\
\hline AOAON4STN1 & Cathelicidin-1-like & 123.6 & 7.5 & 64.7 & 7.5 & $<.0001$ \\
\hline F1MHS5 & Protein S100-A9 & 126.6 & 12.6 & 51.8 & 12.6 & $<.0001$ \\
\hline F1N726 & Glycoprotein 2 & 128.6 & 8.2 & 59.3 & 8.2 & $<.0001$ \\
\hline G3MXB5 & Immunoglobulin IgA heavy chain constant region, partial & 129.1 & 7.6 & 40.4 & 7.6 & $<.0001$ \\
\hline P28782 & Protein S100-A8 & 125.7 & 12.0 & 49.6 & 12.0 & $<.0001$ \\
\hline P79105 & Protein S100-A12 & 125.7 & 10.0 & 55.0 & 10.0 & $<.0001$ \\
\hline P81265 & Polymeric immunoglobulin receptor & 123.9 & 7.1 & 54.5 & 7.1 & $<.0001$ \\
\hline Q3SYR8 & Immunoglobulin J chain & 114.5 & 4.7 & 63.2 & 4.7 & $<.0001$ \\
\hline $\mathrm{F} 1 \mathrm{MH} 40$ & IGK protein & 116.7 & 10.5 & 55.8 & 10.5 & 0.0001 \\
\hline G3N2D7 & Immunoglobulin light chain, partial & 91.4 & 4.8 & 63.6 & 4.8 & 0.0001 \\
\hline F1MX83 & Protein S100 & 126.6 & 8.4 & 79.1 & 8.4 & 0.0002 \\
\hline Q1JPB0 & Leukocyte elastase inhibitor & 117.1 & 9.7 & 62.2 & 9.7 & 0.0002 \\
\hline E1BF48 & CD177 molecule & 117.8 & 12.9 & 48.5 & 12.9 & 0.0003 \\
\hline G5E5V1 & Immunoglobulin iota chain-like, partial (TPA) & 104.4 & 8.7 & 57.2 & 8.7 & 0.0003 \\
\hline E1BGN3 & Histone $\mathrm{H} 3$ & 114.7 & 13.4 & 44.9 & 13.4 & 0.0005 \\
\hline A0A0A0MP90 & Histone H2A & 118.2 & 13.9 & 47.8 & 13.9 & 0.0006 \\
\hline P24627 & Lactotransferrin & 109.2 & 12.4 & 47.7 & 12.4 & 0.0008 \\
\hline P56425 & Cathelicidin-7 & 121.9 & 11.3 & 66.1 & 11.3 & 0.0008 \\
\hline P60712 & Actin, cytoplasmic 1 & 117.0 & 8.3 & 75.6 & 8.3 & 0.0008 \\
\hline F1MUD2 & Histone H2B & 122.6 & 17.0 & 41.3 & 17.0 & 0.0011 \\
\hline Q17QG8 & Histone H2A & 110.6 & 13.5 & 46.1 & 13.6 & 0.0012 \\
\hline F1N514 & CD5 antigen-like precursor & 107.0 & 6.9 & 75.2 & 6.9 & 0.0018 \\
\hline P62803 & Histone $\mathrm{H} 4$ & 123.7 & 16.0 & 50.4 & 16.0 & 0.0018 \\
\hline G5E513 & IgM heavy chain constant region, secretory form, partial & 109.7 & 7.6 & 76.1 & 7.6 & 0.0025 \\
\hline F1N650 & Annexin & 118.1 & 13.8 & 57.6 & 13.8 & 0.0027 \\
\hline G5E5T5 & Immunoglobulin M heavy chain secretory form & 109.6 & 7.1 & 78.7 & 7.1 & 0.0030 \\
\hline F1N5M2 & Vitamin D-binding protein & 103.8 & 7.7 & 72.1 & 7.7 & 0.0048 \\
\hline F1MCF8 & IGL@ protein & 104.1 & 13.0 & 51.1 & 13.0 & 0.0053 \\
\hline P48616 & Vimentin & 112.9 & 9.1 & 75.7 & 9.1 & 0.0053 \\
\hline G3MWV5 & Histone cluster $1 \mathrm{H} 1$ family member e & 108.0 & 17.5 & 38.4 & 17.6 & 0.0065 \\
\hline F1N116 & Gelsolin & 110.8 & 6.4 & 85.6 & 6.4 & 0.0070 \\
\hline A0A140T881 & Apolipoprotein E & 113.9 & 6.2 & 89.4 & 6.2 & 0.0071 \\
\hline A6QNL0 & Monocyte differentiation antigen CD14 & 125.9 & 7.4 & 97.2 & 7.4 & 0.0074 \\
\hline F1MLW8 & Immunoglobulin lambda-1 light chain-like isoform X5 & 99.3 & 10.0 & 62.1 & 10.0 & 0.0108 \\
\hline G3N0V2 & Keratin 1 & 110.8 & 5.9 & 88.9 & 5.9 & 0.0112 \\
\hline G3X7A5 & Complement C3 & 111.1 & 8.6 & 82.7 & 8.6 & 0.0217 \\
\hline P01888 & Beta-2-microglobulin & 112.3 & 18.4 & 51.9 & 18.5 & 0.0241 \\
\hline G3NOVO & Secreted immunoglobulin gamma2 heavy chain constant region, partial & 104.1 & 16.7 & 54.0 & 16.7 & 0.0373 \\
\hline G5E604 & TPA: immunoglobulin iota chain-like & 95.7 & 8.6 & 70.7 & 8.6 & 0.0435 \\
\hline
\end{tabular}


Table 4 Milk fat globule membrane proteins that were present at higher abundance in colostrum and milk collected at milkings 1 , $2,4$, and 14 postpartum from primiparous (PP; $n=10$ ) cows compared with multiparous (MP, $n=10)$ cows. Average abundance across milkings is presented within parity

\begin{tabular}{|c|c|c|c|c|c|c|}
\hline \multirow{2}{*}{$\begin{array}{l}\text { Accession } \\
\text { number }\end{array}$} & \multirow[t]{2}{*}{ Description } & \multicolumn{2}{|l|}{ MP } & \multicolumn{2}{|l|}{ PP } & \multirow{2}{*}{$\begin{array}{l}P \text { - } \\
\text { value }\end{array}$} \\
\hline & & Value & SE & Value & SE & \\
\hline F1MLZ1 & Cytochrome b reductase 1 & 68.3 & 11.1 & 109.8 & 11.1 & 0.0105 \\
\hline P15497 & Apolipoprotein A-I & 102.5 & 7.8 & 130.5 & 7.8 & 0.0129 \\
\hline F1MGC2 & Non-secretory ribonuclease isoform $\mathrm{X} 1$ & 98.8 & 10.4 & 136.2 & 10.4 & 0.0130 \\
\hline F6QVC9 & Annexin & 102.0 & 10.4 & 136.3 & 10.4 & 0.0218 \\
\hline P02662 & Alpha-S1-casein & 89.8 & 14.9 & 139.1 & 14.9 & 0.0222 \\
\hline E1BHI7 & Butyrophilin subfamily 1 member A1 & 108.1 & 15.4 & 158.6 & 15.4 & 0.0234 \\
\hline P19035 & Apolipoprotein C-III & 89.7 & 8.8 & 115.5 & 8.8 & 0.0410 \\
\hline
\end{tabular}

days in milk and reported that several immune-related proteins were lower at $7 \mathrm{~d}$ postpartum compared with the colostrum phase, including lactoransferrin and clusterin, which were both 2.8 fold lower at $7 \mathrm{~d}$ postpartum compared with the colostrum phase [5]. This was similar to our observation of higher abundances of immune-associate proteins in the MFGM proteome in M1 versus M14. Higher presence of several immune-associated proteins in M1, including not only immunoglobulins but also other proteins that play roles in pathogen detection and the immune response, were apparent through statistical analysis of protein abundances (Table 1) and GO comparison (Fig. 3). We further observed a lower abundance of vitamin D-binding protein, hemopexin, serum amyloid A, and lactadherin at M14 compared with M1. These 4 proteins are diverse in their actions and are ubiquitous in the body; however, they are all involved in supporting host immunity [44-46]. Conversely, butyrophilin subfamily 1 member $1 \mathrm{~A}$ was higher in M14 compared with M1 in the current study. While butyrophilin subfamily 1 member $1 \mathrm{~A}$ does belong to the immunoglobulin family [47], the higher abundance of this protein at M14 is not unexpected. As previously reported, this increase is likely due to its key role in milk fat globule synthesis in concert with perilipin 2 [38]. Both of these proteins were higher in M14 compared with M1.

Interestingly, butyrophilin subfamily 1 member $1 \mathrm{~A}$ abundance may also be affected by PAR, as E1BHI7 was consistently higher in PP versus MP cows. However, peptide counts of another sequence linked with butyrophilin 1 member 1A (P18892) did not demonstrate this trend. This disparity may be a result of amino acid sequence overlap with other proteins and requires further research. Apart from this protein, PAR affected 46 proteins (Tables 3 and 4) in the current experiment. There is a paucity of published data characterizing the impact of PAR on the MFGM proteome. However, hypotheses surrounding the influence of PAR on the MFGM proteome can be formed based on our knowledge of other impacts of PAR on milk production, as well as known
GO of identified proteins. MP cows are known to have higher milk and component yields than PP cows, likely leading to an overarching increase in the abundances of individual proteins associated with milk fat and protein synthesis and secretion in MP cows, many of which may be associated with the MFGM (factor 1 for consideration). Ultimately, the higher productivity of MP cows is normally due to higher rates of cell differentiation in the MP mammary gland compared to that of PP cows [48], which would suggest a higher abundance of secreted proteins related to mammary energetics and cellular metabolism in MP cows (factor 2 for consideration). In addition, the milk fat droplet size appears to be positively correlated to fat yield [49] and saturated fatty acid content $[3,50]$, which are higher in milk from MP cows $[29,51$, 52]. It could therefore be extrapolated that MP cows may have increased secretion of proteins associated with mammary de novo fatty acid synthesis (factor 3 for consideration). Finally, the observation that MP cows typically secrete colostrum containing higher immunoglobulin content [29] may also elude to a more concerted drive to secrete immune-rich colostrum, including a more diverse array of immune-associated protein being secreted as part of the MFGM proteome (factor 4 for consideration). Overall, we observed that $84.8 \%$ of proteins affected by PAR were higher in milk from MP cows compared with PP cows, corroborating the suggestion that MP cows have higher secretory abundances of proteins compared with PP cows. Our additional observation of higher abundances of biogenic proteins (Table 3; Fig. 4), including histones $1 \mathrm{H} 1 \mathrm{E}, \mathrm{H} 2 \mathrm{~A}, \mathrm{H} 2 \mathrm{~B}, \mathrm{H} 3$, and $\mathrm{H} 4$, actin, macroglobulin, and vimentin in the MP cows compared with the PP cows supports the idea of chromatin remodeling and higher cellular differentiation [53-55].

The suggestion that proteins associated with de novo milk fat synthesis would be higher in MP cows did not appear to result in a higher secretory abundance of MFGM proteins associated with milk fat synthesis. While apolipoprotein E abundance was higher in samples from MP cows, additional 
Table 5 Protein abundance within the milk fat globule membrane secreted by 10 primiparous (PP) and 10 multiparous (MP) Holsteins at four milkings postpartum (M1, M2, M4, M14) that were impacted by the interaction of milking and parity (MIL $\times$ PAR)

\begin{tabular}{|c|c|c|c|c|c|c|c|c|c|c|c|c|c|c|}
\hline \multirow{2}{*}{$\begin{array}{l}\text { Accession } \\
\text { number }\end{array}$} & \multirow[t]{2}{*}{ Description } & \multicolumn{3}{|l|}{ M1 } & \multicolumn{3}{|l|}{ M2 } & \multicolumn{3}{|l|}{ M4 } & \multicolumn{3}{|l|}{ M14 } & \multirow{2}{*}{$\begin{array}{l}P- \\
\text { value }\end{array}$} \\
\hline & & $\overline{\mathrm{PP}}$ & MP & $\overline{S E^{1}}$ & $\overline{\mathrm{PP}}$ & MP & SE & $\overline{\mathrm{PP}}$ & MP & SE & $\mathrm{PP}$ & MP & SE & \\
\hline G3MXB5 & $\begin{array}{l}\text { Immunoglobulin IgA heavy chain constant } \\
\text { region, partial }\end{array}$ & 61.6 & 159.2 & 18.8 & 68.2 & 197.3 & 19.5 & 16.6 & 122.9 & 11.9 & 15.1 & 37 & 6.7 & $<.0001$ \\
\hline P81265 & Polymeric immunoglobulin receptor & 79.8 & 146 & 17.5 & 75.4 & 169.6 & 19 & 30.7 & 131.1 & 9.3 & 32.1 & 49.1 & 6.9 & $<.0001$ \\
\hline Q3SYR8 & Immunoglobulin J chain & 89.6 & 159 & 12.4 & 85.5 & 138 & 11.1 & 40.1 & 112.6 & 6 & 37.4 & 48.4 & 6.7 & $<.0001$ \\
\hline $\mathrm{F} 1 \mathrm{MH} 40$ & IGK protein & 92.3 & 210.8 & 38.1 & 76.4 & 122.3 & 13 & 27.4 & 102.1 & 11.1 & 27.3 & 31.5 & 4.4 & 0.0001 \\
\hline G3N2D7 & Immunoglobulin light chain, partial & 89.7 & 120.4 & 12.7 & 71.7 & 94.4 & 9.6 & 43.9 & 108.3 & 9.2 & 49.1 & 42.4 & 5.9 & 0.0002 \\
\hline F1MCF8 & IGL@ protein & 92 & 201.6 & 48.9 & 72.4 & 100.5 & 13.9 & 21.4 & 90.6 & 10.5 & 18.6 & 23.6 & 3.8 & 0.0007 \\
\hline QOVCN9 & Folate receptor 2 (Fetal) & 139.8 & 160.9 & 15.6 & 124.3 & 119.6 & 19.4 & 59 & 97.3 & 6.1 & 47.1 & 39.5 & 4.3 & 0.0007 \\
\hline F1N5M2 & Vitamin D-binding protein & 118.1 & 176.1 & 24.3 & 83.4 & 109.8 & 15.8 & 42.8 & 93.1 & 9.2 & 44 & 36 & 4.9 & 0.0008 \\
\hline F1MHS5 & Protein S100-A9 & 68 & 162.5 & 37.6 & 69.6 & 149.9 & 23 & 38.6 & 161 & 23 & 30.8 & 33.2 & 7.5 & 0.0011 \\
\hline P24627 & Lactotransferrin & 54 & 182 & 45.9 & 53 & 100.2 & 13.8 & 41.2 & 109.8 & 12 & 42.7 & 44.7 & 6.1 & 0.0014 \\
\hline Q1JPB0 & Leukocyte elastase inhibitor & 85 & 180.7 & 32.8 & 67.2 & 118.8 & 14.3 & 49.2 & 122.8 & 12.2 & 47.3 & 46.1 & 8.7 & 0.0024 \\
\hline G5E5V1 & Immunoglobulin iota chain-like, partial (TPA) & 95.1 & 175.5 & 29.6 & 75.2 & 112.8 & 11.4 & 29.6 & 100.6 & 12.6 & 28.9 & 28.8 & 7 & 0.0027 \\
\hline P28782 & Protein S100-A8 & 70 & 151.7 & 33.8 & 66.7 & 160.1 & 22.9 & 37 & 153.9 & 24.4 & 24.8 & 37 & 6 & 0.0031 \\
\hline P19035 & Apolipoprotein C-III & 185.1 & 104.9 & 21.7 & 167 & 117.9 & 26 & 64.7 & 90.1 & 7.6 & 45.2 & 46 & 5 & 0.0054 \\
\hline F1N514 & CD5 antigen-like precursor & 122.2 & 184.4 & 19.8 & 102 & 129.6 & 17.7 & 44.3 & 80.6 & 6.8 & 32.1 & 33.4 & 4.4 & 0.0079 \\
\hline A8YXY3 & Selenoprotein F & 119.9 & 117.7 & 11.5 & 133.6 & 105.3 & 13.9 & 95.2 & 125.3 & 6.2 & 119.7 & 101.5 & 11.6 & 0.0089 \\
\hline P60712 & Actin, cytoplasmic 1 & 95.6 & 157.6 & 26.9 & 90 & 128.8 & 14.7 & 59.6 & 121.1 & 10.4 & 57.2 & 60.3 & 7.2 & 0.0105 \\
\hline G5E5T5 & $\begin{array}{l}\text { Immunoglobulin M heavy chain secretory } \\
\text { form }\end{array}$ & 117.7 & 174.6 & 19.5 & 104.9 & 129.4 & 18.7 & 47.2 & 87.9 & 7.2 & 45 & 46.6 & 5.2 & 0.0111 \\
\hline A8DC37 & Fc-gamma-RII-D & 133.6 & 175.8 & 20.3 & 175.1 & 120.9 & 25.8 & 64.1 & 105.1 & 10.7 & 46.8 & 42.8 & 4.6 & 0.0111 \\
\hline G5E513 & $\begin{array}{l}\text { IgM heavy chain constant region, secretory } \\
\text { form, partial }\end{array}$ & 122.3 & 179.5 & 20.3 & 104.6 & 133.3 & 20.7 & 43.4 & 86.9 & 7.3 & 34 & 38.9 & 4.7 & 0.0113 \\
\hline P79105 & Protein S100-A12 & 81.4 & 151.4 & 22.8 & 82 & 160.8 & 20.7 & 35.3 & 151.3 & 24.7 & 21.4 & 39.2 & 7.1 & 0.0123 \\
\hline P13753 & $\begin{array}{l}\text { BOLA class I histocompatibility antigen, alpha } \\
\text { chain BL3-7 }\end{array}$ & 85.2 & 129.9 & 14.1 & 131.4 & 124.2 & 31.6 & 69.6 & 132 & 11.1 & 77 & 73.2 & 9.8 & 0.0142 \\
\hline F1N726 & Glycoprotein 2 & 69.7 & 126.1 & 17.4 & 90 & 174.4 & 19.4 & 38.6 & 150.6 & 16.5 & 39.1 & 63.2 & 10.9 & 0.0156 \\
\hline Q8SQ28 & Serum amyloid A protein & 146.6 & 101 & 16.4 & 137.4 & 129.5 & 32.4 & 81.2 & 137.2 & 16.1 & 54.4 & 80.7 & 13.7 & 0.0185 \\
\hline P01888 & Beta-2-microglobulin & 56.9 & 163.2 & 65.7 & 74.5 & 111.5 & 24.1 & 39.9 & 140.3 & 23.2 & 36.5 & 34.2 & 7.9 & 0.0198 \\
\hline Q32PA1 & CD59 molecule (CD59 blood group) & 134.8 & 109.6 & 9.4 & 117.8 & 107.1 & 15.5 & 85.9 & 130.4 & 13.5 & 100.5 & 123.1 & 20.3 & 0.0256 \\
\hline G3X7A5 & Complement C3 & 96.4 & 150.4 & 24.8 & 91.3 & 90.8 & 12.5 & 68.2 & 136.2 & 17.7 & 75.1 & 67.1 & 9.2 & 0.0343 \\
\hline P17697 & Clusterin & 153.1 & 144 & 15.8 & 171.3 & 108.2 & 19.5 & 61 & 89.7 & 10.5 & 34.8 & 39.3 & 5.4 & 0.0357 \\
\hline F1MLW8 & $\begin{array}{l}\text { Immunoglobulin lambda-1 light chain-like iso- } \\
\text { form X5 }\end{array}$ & 101.6 & 166.3 & 28.6 & 75.1 & 93.3 & 14.7 & 32.9 & 105.8 & 23.5 & 38.7 & 31.7 & 5.2 & 0.0359 \\
\hline P15497 & Apolipoprotein A-I & 160.1 & 110.2 & 14.5 & 173.4 & 108.5 & 24.2 & 109.3 & 123.4 & 10.6 & 79.4 & 67.9 & 7.6 & 0.039 \\
\hline A0A0A0MP90 & Histone H2A & 58.5 & 125.4 & 37 & 65.4 & 147.1 & 22 & 42.7 & 163.6 & 34.3 & 24.5 & 36.9 & 8.8 & 0.0396 \\
\hline F1N116 & Gelsolin & 103.1 & 146 & 18.6 & 95.1 & 120.3 & 12.9 & 75.4 & 115 & 8.7 & 69 & 62 & 8.4 & 0.0426 \\
\hline AOAON4STN1 & Cathelicidin-1-like & 76.7 & 155.5 & 20.6 & 73.3 & 127.8 & 14.9 & 54.9 & 137.6 & 10.3 & 53.9 & 73.4 & 12.1 & 0.0448 \\
\hline F1MUD2 & Histone $\mathrm{H} 2 \mathrm{~B}$ & 40.2 & 136.8 & 52.1 & 63.6 & 140.8 & 19.9 & 36.8 & 171.9 & 37.4 & 24.6 & 41.1 & 9.5 & 0.0463 \\
\hline
\end{tabular}

protein differences were lacking. This was a somewhat surprising result, but perhaps speaks to the higher rate of intracellular metabolism in the PP gland compared with the MP gland, ultimately resulting in comparable presence of milk fat-associated proteins in the MFGM.
As discussed above, proteins involved in the immune system process were more represented in M1 compared with M14 (Fig. 3); however, they were also higher in samples from MP compared with PP cows (Fig. 4). Several immunoglobulin proteins, lactotransferrin, 


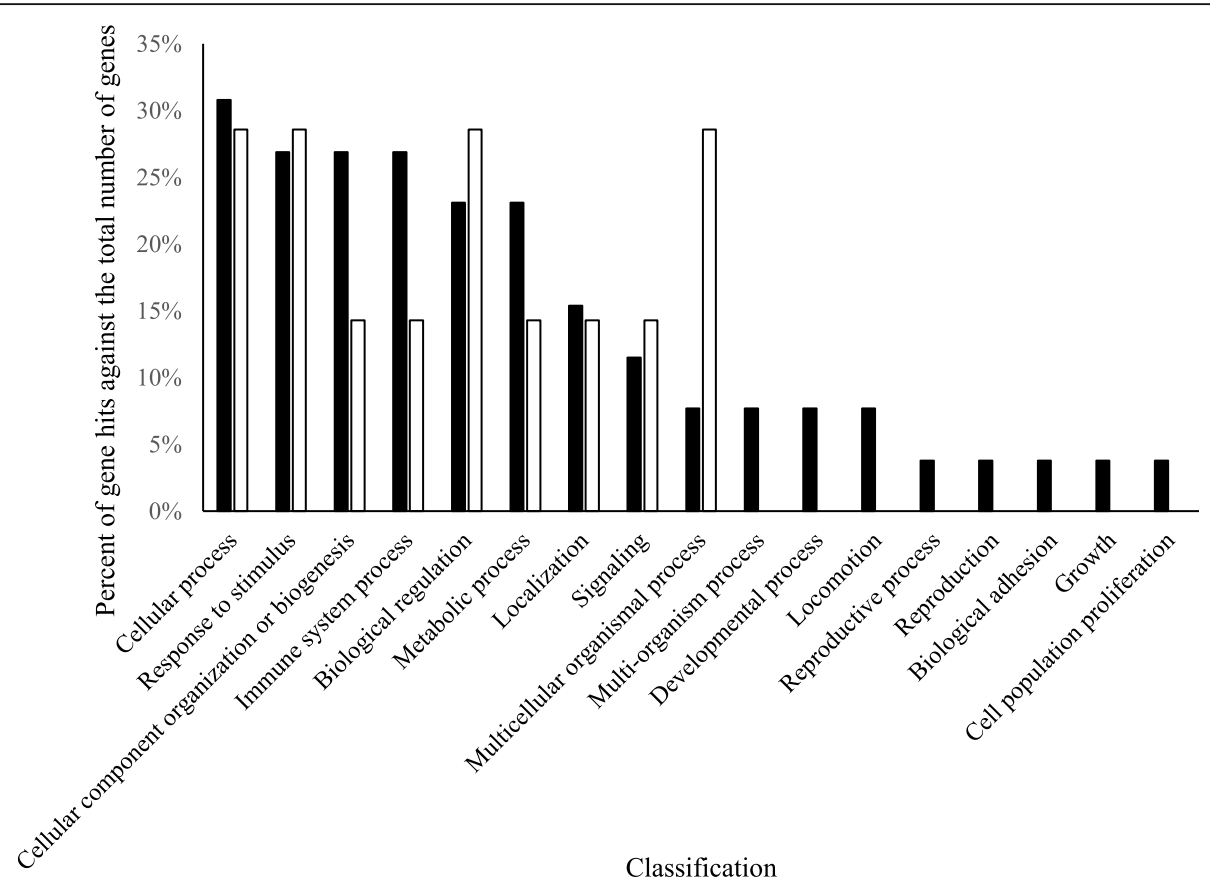

Fig. 4 Biological processes of proteins that were impacted by parity and were higher in multiparous cows compared with primiparous cows (black bars), and lower in multiparous cows compared with primiparous cows (white bars)

complement $\mathrm{C} 3$, vitamin $\mathrm{D}$-binding protein, cathelicidin proteins (1 and 7), S100 and CD proteins (5, 14 and 177) were present at higher abundance in the MFGM proteome from MP compared with PP cows. This in line with our earlier postulation, and may need to be considered when selecting colostrum donor cows.

Three proteins affected by PAR (A6QNL0: monocyte differentiation antigen CD14; G3NOV2: keratin 1; F6QVC9: annexin 5) were not affected by MIL or MIL × PAR. While monocyte differentiation antigen CD14 and keratin 1 abundances were higher in milk from MP cows compared with PP cows, annexin 5 abundance was higher in milk from PP cows. Human keratin is a common contaminant in proteomic analyses; however, the presence of bovine keratin in milk is well documented [56]. Formation of a teat canal keratin plug occurs during the dry period, and is thought to be influenced by PAR [57]. It is feasible that the keratin concentration in milk is indeed also affected by PAR. The observation that annexin 5 was higher in milk from PP cows is a novel finding. Few published studies have investigated the relationship between annexin 5 and PAR; however, annexin 5 is reportedly important for maintenance of placental health and fetal survival in other species [58]. The assessment of milk annexin 5 concentration for use as a biomarker of reproductive health should be further investigated to validate its potential use.

The majority (73.5\%) of proteins affected by the interaction between MIL and PAR demonstrated a pattern whereby the higher protein abundances secreted by MP cows was numerically apparent in M1 but gradually dissipated, resulting in similar protein abundances across MP and PP cows by M14. Lactotransferrin, S100 protein variants, vitamin $\mathrm{D}$-binding protein, and immunoglobulin chain fractions and receptors all followed a similar pattern. The majority of these proteins are involved in immune activity. The implication of a higher presence of immune-associated proteins being affected by the interaction of MIL and PAR underscores the potential importance of selectivity of colostrum donors.

It is interesting to note that $\mathrm{S} 100$ proteins are antimicrobial, and are also present in high abundance in the teat canal lining of dairy cattle [59]. Additionally, variants of S100 proteins serve as calcium sensors [60]. There is an increase in intracellular ionized calcium concentration at the onset of lactation [61]. This is also paired with the demand of calcium for milk production which further increases the need of calcium around parturition. Therefore, implications of calcium mobilization and demand may also contribute to the observed proteomic shifts. Protein $\mathrm{S} 100$-A8, -A9, and -A12 were also affected by the interaction of MIL and PAR and their abundance patterns are presented in Fig. 5. Gelsolin, an abundant protein in the MFGM proteome, is also regulated by calcium [62] and followed a similar pattern to the S100 proteins. Comparative analysis of the bovine and human colostrum proteome using KEGG pathway characterization by Yang et al. [37] highlights the importance of calcium signaling pathways in bovine colostrum, and our results further 


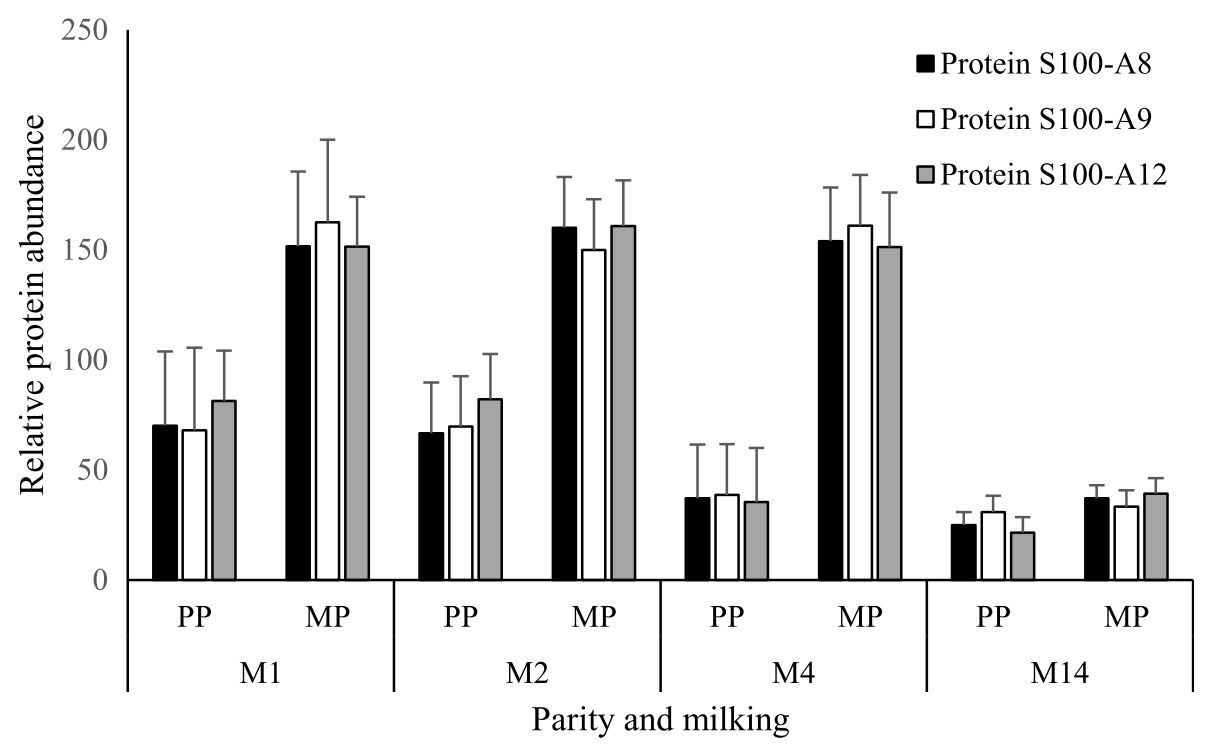

Fig. 5 Abundances of $\mathrm{S} 100$ proteins affected by the interaction of milking and parity (MIL $\times$ PAR) from the MFGM identified by PANTHER in colostrum and milk samples collected from primiparous (PP, $n=10$ ) and multiparous (MP, $n=10$ ) cows at four milkings postpartum (M1, M2, M4, and M14)

contribute to our understanding of calcium-associated proteins in colostrum and factors that affect them.

There are a few exceptions of proteins that were affected by MIL $\times$ PAR and exhibited a higher abundance in colostrum of PP cows compared with MP cows, including apolipoprotein A-I, apolipoprotein C-III, serum amyloid A protein, and clusterin. The abundances of these proteins were similar across PP and MP cows by M14. Hérnandez-Castellano et al. [63] observed higher plasma abundances of apolipoprotein A-IV, B-100, and $\mathrm{E}$ in lambs fed colostrum $2 \mathrm{~h}$ after birth compared with lambs that were not fed colostrum until $14 \mathrm{~h}$ after birth. Given the importance of apolipoproteins in metabolic function [64], further research investigating the impact of feeding PP colostrum on the function of apolipoproteins in neonatal calves is warranted. Additionally, the observation of higher serum amyloid A abundance in the MFGM of MP cows as MIL increased is a novel finding. A review by Hérnandez-Castellano et al. [65] outlines the potential importance of serum amyloid A in colostrum due to its pro-inflammatory function. The current observation that serum amyloid A is affected by MIL $\times$ PAR may be important from a biomarker perspective to better monitor mammary pathogen loads.

\section{Conclusion}

Seventy five percent of the MFGM proteome characterized in the current study was impacted by MIL, PAR, or their interaction, demonstrating the significant impact that these parameters have on the milk protein profile. Consistent with previous results, M1 samples were higher in immuneassociated proteins and regulatory proteins. Contrary to our hypotheses, the MFGM from MP cows comprised higher abundances of proteins associated with cellular differentiation and immune function. In addition, proteins related to milk fatty acid synthesis or secretion were not different in abundance in the MFGM from MP cows compared with PP cows. The observed impact of MIL $\times$ PAR was also a novel and unexpected observation, and supports the need to further develop criteria to assess colostrum quality and parameters for selection of colostrum donors. These results also highlight the potential use of MFGM proteins for use as biomarkers of mammary function. Although results from the effect of MIL were not surprising, the impact of PAR, as well as the interaction of MIL and PAR, display a relationship that requires further investigation.

\section{Supplementary information}

Supplementary information accompanies this paper at https://doi.org/10. 1186/s40104-020-00478-7.

Additional file 1. Complete results dataset of LC-MS/MS from Proteome Discoverer 2.2.

\section{Abbreviations}

$\mathrm{CH}_{3} \mathrm{CN}$ : Acetonitrile; FA: Formic acid; FDR: False-discovery rate; GO: Gene ontology; HCD: Higher-energy collisional dissociation; LC-MS/MS: Liquid chromatography-tandem mass spectrometry; M1: First milking postpartum; M2: Second milking postpartum; M4: Fourth milking postpartum; M14: Fourteenth milking postpartum; MFGM: The milk fat globule membrane; MIL: Milking; MIL $\times$ PAR: Milking $\times$ parity; MP: Multiparous; MS/ MS: Tandem mass spectrometry; PAR: Parity; PBS: Phosphate buffered saline; PP: Primiparous; RIPA: Radioimmunoprecipitation assay; UC: Universal control

\section{Acknowledgments}

The authors would like to thank Richard Scuderi (current location: Lallemand Inc., Chazy, NY, USA) for the guidance and substantial work devoted to 
developing the protocol involved in isolating the protein from the MFGM. Gratitude is also extended to Dr. Ying Wai Lam from the Proteomics Facility at The Vermont Genetics Network for processing samples through the LCMS/MS.

\section{Authors' contributions}

MCH analyzed samples, completed statistical analysis, interpreted data, and was the primary author. MJF participated in sample analysis and provided manuscript edits. AJF-T designed the study, collected samples, and provided manuscript edits. MAS aided in study design, sample collection, and manuscript editing. SLG aided in sample analysis, data interpretation, and manuscript editing. All authors read and approved the final manuscript.

\section{Funding}

This research was funded by USDA HATCH (VT-H02310) and the Alberta Livestock Industry Development Fund. Additional funding support included use of equipment funded by NIH Grant Numbers 5 P30 RR032135 from the COBRE Program of the National Center for Research Resources and 8 P30 GM 103498 from the National Institute of General Medical Sciences. The Vermont Genetics Network Proteomics Facility is supported through the Institutional Development Award (IdeA) from the National Institute of General Medical Sciences of the National Institutes of Health Grant number P20GM103449. The funding body was not involved in the design, analysis, interpretation or writing of the manuscript.

\section{Availability of data and materials}

All data generated or analysed during this study are included in this published article and its supplementary information files.

\section{Ethics approval and consent to participate}

Experimental procedures were performed in accordance with the Canadian Council of Animal Care (CCAC, 1993) and all procedures were approved by the University of Alberta Animal Care and Use Committee for Livestock (AUP 00002015).

\section{Consent for publication}

Not applicable.

\section{Competing interests}

The authors declare that they have no competing interests.

\section{Author details}

'Department of Animal and Veterinary Sciences, The University of Vermont, Burlington, VT 05405, USA. ${ }^{2}$ Department of Animal Biosciences, University of Guelph, Guelph, ON N1G 2W1, Canada. ${ }^{3}$ Department of Agriculture, Food \& Nutritional Science, University of Alberta, Edmonton, AB T6G 2P5, Canada.

Received: 20 January 2020 Accepted: 1 June 2020

\section{Published online: 17 July 2020}

\section{References}

1. Yang $Y$, Zheng $N$, Zhao X, Zhang Y, Han R, Ma L, et al. J. Proteomic characterization and comparison of mammalian milk fat globule proteomes by iTRAQ analysis. J Proteomics. 2015. https://doi.org/10.1016/jjprot.2014.12. 017.

2. Fong BY, Norris CS, MacGibbon AK. Protein and lipid composition of bovine milk-fat-globule membrane. Int Dairy J. 2007. https://doi.org/10.1016/j.idairyj. 2006.05.004.

3. Lopez C. Milk fat globules enveloped by their biological membrane: unique colloidal assemblies with a specific composition and structure. Curr Opin Colloid Interface Sci. 2011. https://doi.org/10.1016/j.cocis.2011.05.007.

4. Mondy BL, Keenan TW. Butyrophilin and xanthine oxidase occur in constant molar proportions in milk lipid globule membrane but vary in amount with breed and stage of lactation. Protoplasma. 1993. https://doi.org/10.1007/ BF01403396.

5. Reinhardt TA, Lippolis JD. Developmental changes in the milk fat globule membrane proteome during the transition from colostrum to milk. J Dairy Sci. 2008. https://doi.org/10.3168/jds.2007-0952.

6. Ji X, Li X, Ma Y, Li D. Differences in proteomic profiles of milk fat globule membrane in yak and cow milk. Food Chem. 2017. https://doi.org/10.1016/j. foodchem.2016.10.097.
7. Nguyen HT, Ong L, Hoque OA, Kentish SE, Williamson N, Ang CS. et al, A proteomic characterization shows differences in the milk fat globule membrane of buffalo and bovine milk. Food Biosci. 2017. https://doi.org/10. 1016/j.fbio.2017.05.004.

8. Bhinder G, Allaire JM, Garcia C, Lau JT, Chan JM, Ryz NR, et al. Milk fat globule membrane supplementation in formula modulates the neonatal gut microbiome and normalizes intestinal development. Sci Rep. 2017. https://doi.org/10.1038/srep45274.

9. Rasmussen JT. Bioactivity of milk fat globule membrane proteins. Aust J Dairy Technol. 2009;64:63-7.

10. Murgiano L, Timperio AM, Zolla L, Bongiorni S, Valentini A, Pariset L. Comparison of milk fat globule membrane (MFGM) proteins of Chianina and Holstein cattle breed milk samples through proteomics methods. Nutrients. 2009. https://doi.org/10.3390/nu1020302.

11. Affolter M, Grass L, Vanrobaeys F, Casado B, Kussmann M. Qualitative and quantitative profiling of the bovine milk fat globule membrane proteome. J Proteome. 2010. https://doi.org/10.1016/j.jprot.2009.11.008.

12. Le TT, Van de Wiele T, Do TNH DG, Struijs K, Devreese B, et al. Stability of milk fat globule membrane proteins toward human enzymatic gastrointestinal digestion. J Dairy Sci. 2012. https://doi.org/10.3168/jds.2011-4947.

13. Ontsouka CE, Bruckmaier RM, Blum JW. Fractionized milk composition during removal of colostrum and mature milk. J Dairy Sci. 2003. https://doi. org/10.3168/jds.S0022-0302(03)73789-8.

14. Demmelmair H, Prell C, Timby N, Lönnerdal B. Benefits of lactoferrin, osteopontin and milk fat globule membranes for infants. Nutrients. 2017. https://doi.org/10.3390/nu9080817.

15. Jørgensen ALW, Juul-Madsen HR, Stagsted J. Colostrum and bioactive, colostral peptides differentially modulate the innate immune response of intestinal epithelial cells. J Pept Sci. 2010. https://doi.org/10.1002/psc.1190.

16. Dander S, Piccioli-Cappelli F, Bignami A, Minuti A, Trevisi E. Metabolic profile and inflammatory response in calves with different intake of immunoglobulins. J Anim Sci. 2016. https://doi.org/10.2527/jam2016-1146.

17. Le A, Barton LD, Sanders JT, Zhang Q. Exploration of bovine milk proteome in colostral and mature whey using an ion-exchange approach. J Proteome Res. 2010. https://doi.org/10.1021/pr100884z.

18. Tacoma R, Gelsinger SL, Lam Y-W, Scuderi RA, Ebenstein DB, Heinrichs AJ, et al. Exploration of the bovine colostrum proteome and effects of heat treatment time on colostrum protein profile. J Dairy Sci. 2017. https://doi. org/10.3168/jds.2017-13211.

19. Tacoma R, Fields J, Ebenstein DB, Lam Y-W, Greenwood SL. Characterization of the bovine milk proteome in early-lactation Holstein and Jersey breeds of dairy cows. J Proteome. 2016. https://doi.org/10.1016/j.jprot.2015.09.024.

20. Ma Y, Zhang L, Wu Y, Zhou P. Short communication: changes in milk fat globule membrane proteome after pasteurization in human, bovine and caprine species. Food Chem. 2019. https://doi.org/10.1016/j.foodchem.2018.12.015.

21. Yang M, Song D, Cao X, Wu R, Liu B, Ye W, et al. Comparative proteomic analysis of milk-derived exosomes in human and bovine colostrum and mature milk samples by iTRAQ-coupled LC-MS/MS. Food Res Int. 2017. https://doi.org/10.1016/j.foodres.2016.11.041.

22. Yang $M$, Cong M, Peng X, Wu J, Wu R, Liu B, et al. Quantitative proteomic analysis of milk fat globule membrane (MFGM) proteins in human and bovine colostrum and mature milk samples through iTRAQ labeling. Food Funct. 2016. https://doi.org/10.1039/C6FO00083E.

23. Sevi A, Taibi L, Albenzio M, Muscio A, Annicchiarico G. Effect of parity on milk yield, composition, somatic cell count, renneting parameters and bacteria counts of Comisana ewes. Small Ruminant Res. 2000. https://doi. org/10.1016/S0921-4488(99)00133-9.

24. Gurmessa J, Melaku A. Effect of lactation stage, pregnancy, parity and age on yield and major components of raw milk in bred cross Holstein Friesian cows. World J Dairy Food Sci. 2012. https://doi.org/10.5829/idosi.wjdfs.2012.7.2.64136.

25. Knight $\mathrm{CH}$, Peaker M. Development of the mammary gland. J Reprod Fertil. 1982. https://doi.org/10.1530/jrf.0.0650521.

26. Freetly HC, Nienaber JA, Brown-Brandl T. Partitioning of energy during lactation of primiparous beef cows. J Anim Sci. 2006. https://doi.org/10. 2527/jas.2005-534

27. Lang SL, Iverson SJ, Bowen WD. Primiparous and multiparous females differ in mammary gland alveolar development: implications for milk production. J Exp Biol. 2012. https://doi.org/10.1242/jeb.067058.

28. CCAC. In: Olfert ED, Cross GM, AA MW, editors. Guide to the care and use of experimental animals, vol. 1. Ottawa: Canadian Council on Animal Care; 1993. 
29. Fisher-Tlustos AJ, Hertogs K, van Niekerk JK, Nagorske M, Haines DM, Steele MA. Oligosaccharide concentrations in colostrum, transition milk, and mature milk of primi- and multiparous Holstein cows during the first week of lactation. J Dairy Sci. 2020. https://doi.org/10.3168/jds.2019-17357.

30. Fahey MJ, Fisher AJ, Steele MA, Greenwood SL. Characterization of the colostrum and transition milk proteomes from primiparous and multiparous Holstein dairy cows. J Dairy Sci. 2019. https://doi.org/10.3168/jds.2019-17094.

31. Scuderi RA, Ebenstein DB, Lam Y-W, Kraft J, Greenwood SL. Inclusion of grape marc in dairy cattle rations alters the bovine milk proteome. J Dairy Res. 2019. https://doi.org/10.1017/S0022029919000372.

32. Benjamini $Y$, Hochberg $Y$. On the adaptive control of the false discovery rate in multiple testing with independent statistics. J Ed Behav Stat. 2000;25:60-83.

33. Chen $\mathrm{C}$, Huang $\mathrm{H}, \mathrm{Wu} \mathrm{CH}$. Protein bioinformatics databases and resources methods. Mol Biol. 2017. https://doi.org/10.1007/978-1-4939-6783-4_1.

34. Mi H, Huang X, Muruganujan A, Tang H, Mills C, Kang D, et al. PANTHER version 11: expanded annotation data from gene ontology and Reactome pathways, and data analysis tool enhancements. Nucleic Acid Res. 2017:45:D183-9.

35. Camacho C, Coulouris G, Avagyan V, Ma N, Papadopoulos J, Bealer K, et al. BLAST+: architecture and applications. BMC Bioinform. 2008. https://doi.org/ 10.1186/1471-2105-10-421

36. Greenwood SL, Honan MC. Symposium review: characterization of the bovine milk protein profile using proteomic techniques. J Dairy Sci. 2019. https://doi.org/10.3168/jds.2018-15266.

37. Yang $M$, Peng $X$, Wu J, Wu R, Liu B, Ye W, et al. Differential proteomic analysis of milk fat globule membrane proteins in human and bovine colostrum by iTRAQ-coupled LC-MS/MS. Eur Food Res Technol. 2017. https://doi.org/10.1007/s00217-016-2798-6.

38. Robenek H, Hofnagel O, Buers I, Lorkowski S, Schnoor M, Robenek MJ, et al. Butyrophilin controls milk fat globule secretion. PNAS. 2006. https://doi.org/ 10.1073/pnas.0600795103.

39. Russell TD, Palmer CA, Orlicky DJ, Fischer A, Rudolph MC, Neville MC, et al. Cytoplasmic lipid droplet accumulation in developing mammary epithelial cells: roles of adipophilin and lipid metabolism. J Lipid Res. 2007. https://doi org/10.1194/jlr.M600474-JRL200

40. Monks J, Dzieciatkowska M, Bales ES, Orlicky DJ, Wright RM, McManaman JL. Xanthine oxidoreductase mediates membrane docking of milk-fat droplets but is not essential for apocrine lipid secretion. J Physiol. 2016. https://doi. org/10.1113/JP272390.

41. Bionaz M, Hurley W, Loor J. Milk protein synthesis in the lactating mammary gland: insights from transcriptomics analyses. Hurley SL ed. Roijeka, Croat:: InTech. Milk protein. 2012. https://doi.org/10.5772/46054.

42. Li M, Li W, Kong F, Kang S, Liang X, Han H, et al. Metabolomics methods to analyze full spectrum of amino acids in different domains of bovine colostrum and mature milk. Eur Food Res Technol. 2020. https://doi.org/10. 1007/s00217-019-03385-y.

43. Hérnandez-Castellano LE, Almeida AM, Renaut J, Argüello A, Castro N. A proteomics study of colostrum and milk from the two major small ruminant dairy breeds from the Canary Islands: a bovine milk comparison perspective. J Dairy Res. 2016. https://doi.org/10.1017/S0022029916000273.

44. Delanghe JR, Speeckaert R, Speeckaert MM. Behind the scenes of vitamin D binding protein: more than vitamin D binding. Best Pract Res Clin Endocrinol Metab. 2015. https://doi.org/10.1016/j.beem.2015.06.006.

45. Sabha BH, Alzahrani F, Almehdar HA, Uversky VN, Redwan EM. Disorder in the milk proteins: lactadherin multifunctionality and structure. Curr Protein Pept Sci. 2018. https://doi.org/10.2174/1389203719666180608091849.

46. Tolosano E, Altruda F. Hemopexin: structure, function, and regulation. DNA Cell Biol. 2012. https://doi.org/10.1089/104454902753759717.

47. Jiménez-Flores R, Higuera-Ciapara I, Pouliot Y. Beverages based on milk fat globule membrane (MFGM) and other novel concepts for dairy-based functional beverages. In: Functional and speciality beverage technology. Cambridge: Woodhead Publishing; 2009. p. 281-96.

48. Miller N, Delbecchi L, Petitclerc D, Wagner GF, Talbot BG, Lacasse P. Effect of stage of lactation and parity on mammary gland cell renewal. J Dairy Sci. 2006. https://doi.org/10.3168/jds.S0022-0302(06)72517-6.

49. Fleming A, Schenkel FS, Chen J, Malchiodi F, Ali RA, Mallard M, et al. Variation in fat globule size in bovine milk and its prediction using midinfrared spectroscopy. J Dairy Sci. 2017. https://doi.org/10.3168/jds.201611427.

50. Lars W, Stagsted J, Bjorck L, Nielson JH. Milk fat globule size is affected by fat production in dairy cows. Int Dairy J. 2004. https://doi.org/10.1016/j. idairyj.2004.03.005.
51. Samková E, Koubová J, Hasoňová L, Hanuš O, Kala R, Kváč M, et al. Joint effects of breed, parity, month of lactation, and cow individuality on the milk fatty acids composition. Mljekarstvo: časopis za unaprjeđenje proizvodnje i prerade mlijeka. 2018. https://doi.org/10.15567/mljekarstvo. 2018.0203.

52. Hanuš O, Samková E, Křlžová L, Hasoňová L, Kala R. Role of fatty acids in milk fat and the influence of selected factors on their variability - a review. Molecules. 2018. https://doi.org/10.3390/molecules23071636.

53. Monteiro FL, Vitorino R, Wang J, Cardoso H, Laranjeira H, Simões J, et al. The histone $\mathrm{H} 2 \mathrm{~A}$ isoform Hist2h2acc is a novel regulator of proliferation and epithelial-mesenchymal transition in mammary epithelial and breast cancer cells. Cancer Lett. 2017. https://doi.org/10.1016/j.canlet.2017.03.007.

54. Gilles C, Polette M, Zahm JM, Tournier JM, Volders L, Foidart JM, et al. Vimentin contributes to human mammary epithelial cell migration. J Cell Sci. 1999:112:4615-25.

55. Peuhu E, Virtakoivu R, Mai A, Wärri IJ. Epithelial vimentin plays a functional role in mammary gland development. Development. 2017. https://doi.org/ 10.1242/dev.154229.

56. Bitman J, Wood DL, Bright SA, Miller RH, Capuco AV, Roche A, et al. Lipid composition of teat canal keratin collected before and after milk from Holstein and Jersey cows. J Dairy Sci. 1991;74:414-20.

57. Dingwell RT, Leslie KE, Schukken YH, Sargeant JM, Timms LL, Duffield TF, et al. Association of cow and quarter-level factors at drying-off with new intramammary infections during the dry period. Preventitive Vet Med. 2004; 63:75-89.

58. Ueki H, Mizushina T, Laoharatchatathanin T, Terashima R, Nishimura $Y$, Rieanrakwong D, et al. Loss of maternal annexin A5 increases the likelihood of placental platelet thrombosis and foetal loss. Sci Rep. 2012. https://doi. org/10.1038/srep00827.

59. Smolenski GA, Cursons RT, Hine BC, Wheeler T. Keratin and S100 calciumbinding proteins are major constitutents of the bovine teat canal lining. Vet Res. 2015. https://doi.org/10.1186/s13567-015-0227-7.

60. Zimmer DB, Eubanks JO, Ramakrishnan D, Criscitiello MF. Evolution of the S100 family of calcium sensor proteins. Cell Calcium. 2013;53:170-9.

61. Kimura K, Reinhardt TA, Goff JP. Parturition and hypocalcemia blunts calcium signals in immune cells of dairy cattle. J Dairy Sci. 2006. https://doi. org/10.3168/jds.S0022-0302(06)72335-9.

62. Scumaci D, Trimboli F, Dell'Aquila L, Concolino A, Pappalanni G, Tammè L, et al. Proteomics-driven analysis of ovine whey colostrum. PLoS One. 2015. https://doi.org/10.1371/journal.pone.0117433.

63. Hérnandez-Castellano LE, Argüello A, Almeida AM, Castro N, Bendixen E. Colostrum protein uptake in neonatal lambs examined by descriptive and quantitative liquid chromatography-tandem mass spectrometry. J Dairy Sci. 2015. https://doi.org/10.3168/jds.2014-8143.

64. Dominiczak MH, Caslake MJ. Apolipoproteins: metabolic role and clinical biochemistry applications. Ann Clin Biochem. 2011. https://doi.org/10.1258/ acb.2011.011111.

65. Hérnandez-Castellano LE, Almeida AM, Renaut J, Castro N, Argüello A. The colostrum proteome, ruminant nutrition and immunity: a review. Curr Prot Pept Sci. 2014. https://doi.org/10.2174/1389203715666140221124622.

Ready to submit your research? Choose BMC and benefit from:

- fast, convenient online submission

- thorough peer review by experienced researchers in your field

- rapid publication on acceptance

- support for research data, including large and complex data types

- gold Open Access which fosters wider collaboration and increased citations

- maximum visibility for your research: over $100 \mathrm{M}$ website views per year

At $\mathrm{BMC}$, research is always in progress.

Learn more biomedcentral.com/submission 